\title{
Gender Differences in Professional Career Dynamics: New Evidence from a Global Law Firm
}

Ina Ganguli, Ricardo Hausmann, and Martina Viarengo

CID Faculty Working Paper No. 378

April 2020

(C) Copyright 2020 Ganguli, Ina; Hausmann, Ricardo;

Viarengo, Martina; and the President and Fellows of Harvard

College
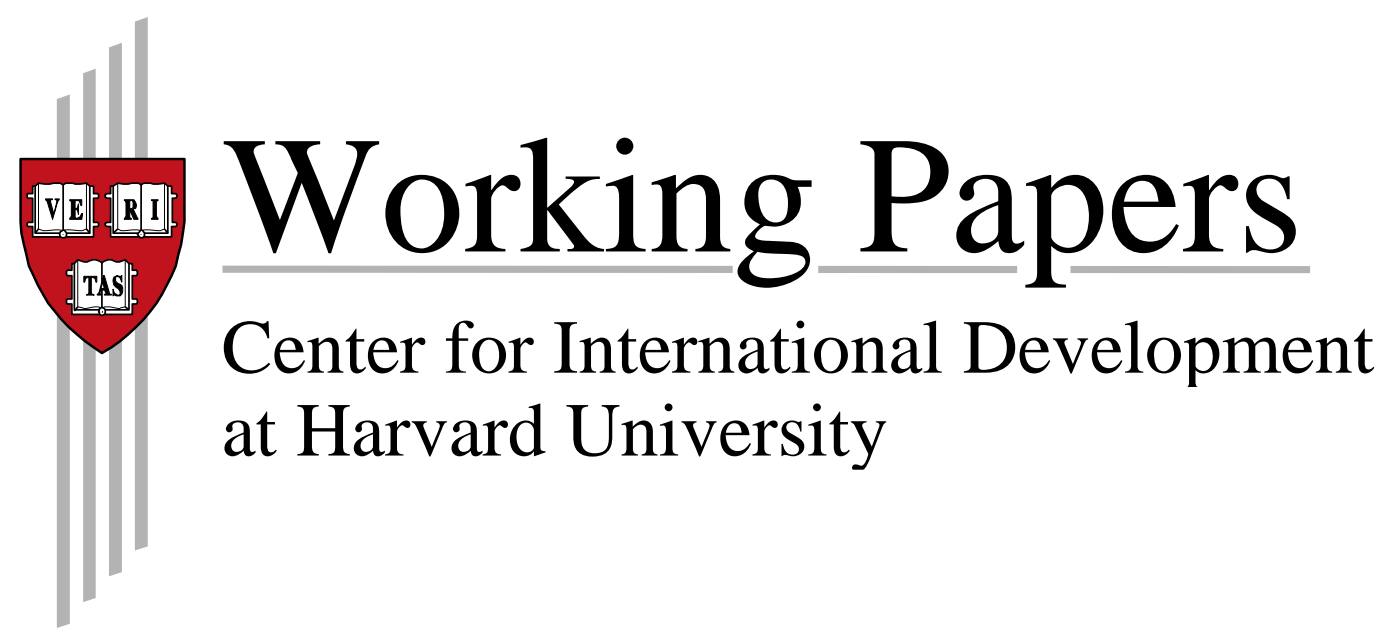


\title{
Gender Differences in Professional Career Dynamics:
}

\author{
New Evidence from a Global Law Firmı,2
}

\author{
Ina Gangulia, Ricardo Hausmann $b, c, d$, Martina Viarengoe,d,f
}

\begin{abstract}
a University of Massachusetts, Amherst (200 Hicks Way, Amherst, MA 01003 - USA)
${ }_{b}$ Harvard Kennedy School (79 John F. Kennedy Street, Cambridge, MA 02138 - USA)

c Santa Fe Institute

${ }_{d}$ Center for International Development at Harvard University

eThe Graduate Institute, Geneva (Chemin Eugène-Rigot 2, 1202 Geneva-Switzerland)

${ }_{f}$ CESifo and IZA
\end{abstract}

\section{April 2020}

\begin{abstract}
We examine gender gaps in career dynamics in the legal sector using rich panel data from one of the largest global law firms in the world. The law firm studied is representative of multinational law firms and operates in 23 countries. The sample includes countries at different stages of development. We document the cross-country variation in gender gaps and how these gaps have changed over time. We show that while there is gender parity at the entry level in most countries by the end of the period examined, there are persistent raw gender gaps at the top of the organization across all countries. We observe significant heterogeneity among countries in terms of gender gaps in promotions and wages, but the gaps that exist appear to be declining over the period studied. We also observe that women are more likely to report exiting the firm for family and work-life balance reasons, while men report leaving for career advancement. Finally, we show that various measures of national institutions and culture appear to play a role in the differential labor-market outcomes of men and women.
\end{abstract}

Keywords: gender gaps; human capital; job mobility; promotion; culture; legal sector

JEL codes: I26, J16, J62, M51, Z

1 Corresponding author - Martina Viarengo (email: martina.viarengo@ graduateinstitute.ch; phone: +41 22 908 5937; fax: +4122733 3049).

2 We gratefully acknowledge support received from the Women and Public Policy Program and the Women's Leadership Board at the Harvard Kennedy School, and the Center for International Development at Harvard University. We would like to thank Daron Acemoglu, Oriana Bandiera, Iris Bohnet, Claudia Goldin, Marcela Escobari, Raquel Fernández, Richard B. Freeman, Fidan Kurtulus, Lant Pritchett and Ugo Panizza for helpful discussions and suggestions. We also thank seminar participants at the Asian Development Bank, Stockholm Institute of Transition Economics, Stockholm School of Economics, University of Bergen, University of Massachusetts Amherst and Harvard University for comments on an earlier draft of the paper. 


\section{INTRODUCTION}

Gender differences in labor-market outcomes among professionals persist in various sectors of the economy. Despite the narrowing of the gender gap in education in many countries (Pritchett and Viarengo, 2010; Ganguli, Hausmann and Viarengo, 2014), women's underrepresentation in the corporate, financial and legal sectors, especially at the top levels, has been widely documented (e.g. Blau and Winkler, 2018; Bertrand et al. 2010; Bertrand and Hallock, 2001; Wolfers, 2006, Ganguli, Hausmann and Viarengo, 2018). These gaps appear to emerge despite comparable investments in human capital and similar self-reported aspirations to reach leadership positions and may have significant consequences on the overall level of productivity and performance of organizations (Aisenbrey and Bruckner, 2008; Eagly and Carli, 2007; Muravyev, Talavera and Shäfer, 2009; Cohen et al., 1998; Elvira and Cohen, 2001, Bertrand, 2011). These gaps seem to persist in spite of the relatively recent introduction of interventions such as family-friendly policies, gender neutralizing childcare and affirmative action initiatives in leadership (Bertrand, 2018). The legal profession presents some of the largest gender gaps in leadership positions when compared to other professions3, although there has been almost parity at the entry level in different countries for many years.

In this paper, we aim to provide the first consistent and comparable analysis of gender differences in employment trends and labor-market outcomes in the legal sector in an international

3 Larger gaps only appear to be among venture capital partners and leading tech company top ranks (Brush and Blank 2014; Fortune 2014). 
perspective4. We draw upon a rich longitudinal dataset of all employees working in one of the largest global law firms, which operates in 23 countries, allowing us to closely examine career paths and wages for employees working in the same firm but in different countries. These unique data allow us to examine the following questions: At what stage in the career trajectory do gender gaps in the legal sector emerge and why? Are gender gaps in the legal sector present around the world? If so, how have they changed over time across countries?

Gender gaps in the legal sector have been widely acknowledged especially in some of the leading international law firms (McKinsey 2017; Rikleen, 2013; Catalyst, 2013; National Association of Women Lawyers, 2014; "Gender Gap at Top Law Firms" in the Financial Timess). Several factors, widely acknowledged, make the legal sector an important case study to examine gender gaps among professionals. Among these, the rapid expansion of female employment in a sector that used to be only for men (e.g., Goldin, 2015), and the related closing of the gender gap in legal education, leading to a large representation of women in elite institutions. In addition, the partnership track and the homogeneity of explicit criteria for promotion make lawyers' performance easier to compare. Technological change, globalization and the 2008 global financial crisis, among other changes, have shaped the legal sector and led to significant changes in the delivery of legal services in several countries. In addition to providing new facts about gender gaps in career dynamics for a large share of the global legal workforce, by examining employees from one firm working across many countries, we can shed light on whether cross-country differences in institutions and culture contribute to gender differences in mobility within the firm, similar to

4 Studies in the legal sector have mainly focused on the United States (e.g., Azmat and Ferrer, 2017; Noonan et al., 2005; Wood et al. 1993). Evidence is especially scant in the context of developing countries.

5 September 7, 2008. 
the approach in the seminal work of Hofstede (1984). Moreover, an advantage of focusing on employees within one firm is that one channel for gender disparities of women sorting into low paying and low growth firms does not apply, as all the lawyers in the firm work full-time and are expected to pursue the same career path.

The rest of the paper is structured as follows. Section II provides background and institutional details about the global law firm that we study. Section III provides a description of the dataset and empirical strategy. The results are presented and discussed in Section IV. Section V concludes.

\section{BACKGROUND: THE FIRM IN AN INTERNATIONAL CONTEXT}

One of the five "Magic Circle" law firms headquartered in the United Kingdom, the firm we study is among the top 10 of the largest international law firms measured by number of lawyers employed and by share of world revenue, and thus represents an important part of the global legal workforce. This firm is representative of the large multinational law firms, in that they share comparable cost structures, earning practices, and employment structures. Among other services, they address the demand, which has been rapidly growing in the last decades, for the provision of legal services which involve multiple legal systems (Drolshammer and Pfeifer, 2001). Many of these law firms have kept growing over time and increased their presence in other countries through mergers with local law firms. Top law firms have been establishing offices in different regions of the world over the past few years with the aim of increasing their activity in these markets. Multinational law firms represent an increasingly large share of the global market. They also face similar characteristics with respect to the gender ratio along the career trajectory, with 
about parity at the entry-level position and an important gender imbalance skewed towards men at the highest ranks of the organization. 6

Leveraging data from one representative firm has several advantages, and allow us to carry out an analysis on the dynamics of gender gaps within the same sector, but in an international context. First, it provides us with a rich, as well as comparable and consistent, dataset on employees over time across many countries. As of 2019, the firm employed 2,920 lawyers and 2,520 other staff across 30 offices in 20 countries. Our sample includes 6,585 lawyers who worked at any of the firm's offices in 23 countries at any point during 2003-2011. Thirty-one offices are located in Europe, eight in Asia and the Middle East, one in Latin America and one in North America. As shown in Table 1, the offices vary in terms of size and share of female lawyers over the period studied from 2003-2011.

A benefit of restricting our analysis to one industry and firm is that there is a clear hierarchy of ranks. Figure 1 shows the hierarchy of the ranks and typical time to promotion in the firm. Much of our analysis is focused on employees at the Associate (entry-level) and Managing Associate levels, and the transitions from Associate to Managing Associate, and from Managing Associate to Partner. There is heterogeneity across regions, and across countries within regions with respect to the structure of the partnership track. On average, as shown in Figure 1, after four years in Europe and North America (five years in Asia, Middle East and Latin America), lawyers are eligible for promotion to Managing Associate. Then four additional years is the minimum

6 Selected relevant coverage in the press: “Why Law Firms must Change how they Work” (2019); “Law Firms' Gender Diversity Programs Aren't Keeping Women in the Industry" (2017); “A Few Good Women” (2015); "Female Lawyers Still Battle Gender Bias - Despite Advances, Women Still Lag Behind Men in Billing Rate, Management Roles" (2014). This is a general phenomenon experienced by leading law firms. These firms are puzzled because in spite of having in place gender neutral policies they find that employment outcomes are not. There is now a wide awareness over this issue and a commitment to reducing gender differences (see The Times, May 22, 2014). 
eligibility requirement for promotion to Partner in Europe and North America (two additional years in Asia, Middle East and Latin America).7

Promotion decisions are usually made by a small committee of senior lawyers, including the direct supervisor, who evaluates the performance of their junior colleague. Promotion depends on the lawyer reaching a given threshold of productivity, and on a higher-ranked position becoming available. Thus, it also depends on the other equally ranked lawyers' performance, as in a tournament. This is because there are a limited number of top-ranked (partner) positions and thus only the very best candidates (associates) in the end will be promoted.

Galanter and Palay (1991) among others, have documented how the ratio of associates to partners has increased over time in the large law firms, which has led to increasingly competitive tournaments. The institutional practice under which this system works has been known as the "up or out" system, where lawyers who are not promoted must leave the firm. This screening device appears to have existed since the establishment of the modern corporate law firm (Gilson and Mnookin 1988). It is also common to a large number of professional occupations ranging from the military and professional sports to academia (O’Flaherty and Siow, 1995; Lazear and Shaw, 2007).

While the firm for this study does not have a formal up-or-out policy, lawyers who experience a negative decision regarding their promotion would usually leave the law firm. Again, this is something common to a large number of law firms where employment terminates with mutual consent (O'Flaherty and Siow, 1995). O'Flaherty and Siow (1995) derive a stochastic and

7 In the analysis that follows, we omit lawyers who belong to the category of 'Counsel'. In the legal career path, counsels are those lawyers who follow a different career trajectory. That is, this category includes two different type of lawyers: those who are not going to be promoted as partners, as they lack some of the key characteristics required for this position, and those lawyers who in spite of meeting the requirements to become partners, cannot be promoted as there is no position available at the time. Given that this category of lawyers follows a quite distinct career trajectory, and it is not possible to clearly separate and identify the two types of lawyers within this category, in our analysis we focus on the standard career trajectory, which is common to the majority of lawyers working in private law firms. However, similar analysis related to promotion to counsel is available from the authors. 
dynamic model to explain the existence of up-or-out rules and the related organizational structure and growth of law firms. This employment structure together with the system of remuneration leads to a non-linear relationship between compensation and the number and flexibility of hours worked (Landers et al., 1996; Goldin 2014; Goldin and Katz, 2016).

Another benefit of focusing on employees within this firm is the availability of performance appraisal (rating) measures. The appraisal system is used to assess lawyers' yearly performance and for the evaluations related to promotions. It is also meant to be used to provide feedback to lawyers on their performance and on how they can improve. 8 During our period of study, the law firm introduced a uniform appraisal system in order to evaluate in a consistent way lawyers working in any office of any country where the global law firm is located. The globally consistent appraisal mechanism relies on objectives defined in order to match the law firm's strategic objectives. The rating scale consists of a 4-point scale for which each level corresponds to a clear definition of performance (performance level 4 being the top rank vs. performance level 1 being the bottom one). A lawyer's achievement is assessed with respect to their performance, according to whether they met the objectives and key targets set, according to the level of skills and values-driven behaviors they performed, and to the extent to which they added significant value to the team and area of practice area, and how they performed relative to their peers.

\section{DATA AND METHODOLOGY}

Our analysis uses panel data on employees working in the law firm during the period from 2003-2011. Our analytical sample includes yearly observations for the period 2003-11 and

8 The appraisal system consists of a 'core skills document', an 'objective setting' and a 'rating system'. The first two components are designed to provide lawyers with information on what is expected from them at different stages of their career, and on specific targets they have to meet in a given year respectively. 
includes over 6,000 lawyers who work(ed) in one of 33 offices located in 23 countries on four continents. As some of the offices are quite small, for most of our empirical analysis, we restrict the sample to 10 countries that have at least 1 lawyer in each rank in each year and at least 30 associates (entry-level) in 2011: Belgium, Brazil, Germany, Hong Kong, Japan, Poland, Russia, Spain, Sweden, and the United Kingdom.

In our data, we have detailed individual-level information that provides the lawyers' demographic characteristics (age, gender, higher education institution for a subsample), their employment status and career trajectory (position, area of practice within the law firm, wage, bonus, and performance rating) as well as career interruptions (maternity leave) and reason for the change in professional status for a subet-set of individuals (fired, transfer, retirement, personal leave). 9 The main areas of practice include banking, capital markets, competition/antitrust, corporate/mergers and acquisitions, employment and incentives, environment and climate change.

Table 2 shows the characteristics of male and female lawyers by rank for 2003 and 2010. It shows that over the period, the share female for each rank increased, but most for Associates and the least for Partners. At all ranks, women are on average slightly younger than men, but the difference is largest among Partners, suggesting that women are promoted to Partner when they are younger. However, looking at tenure in the firm, at the Associate and Managing Associate levels, women have been with the firm longer than men. For Partners, in 2003, women were with the firm longer as well, but by 2010, women were with the firm for a slightly shorter period of time. Finally, in terms of performance ratings, for both Associate and Managing Associates,

9 We also have information on the level of employment (part-time). However, $96.33 \%$ of the person-year observations are full-time, so we do not use this variable in our analysis. We also have information on the university attended, and added information on university quality from the 2012 Academic Ranking of World Universities (ARWU) developed by the Center for World-Class Universities at Shanghai Jiao Tong University, commonly known as the "Shanghai Ranking". 
women always received lower ratings than men on average. We investigate these gender differences further in a regression framework and results are presented in Section IV.

An important drawback of our dataset is that the firm did not collect information on the number of children of employees. However, we can create a proxy for which female employees have children using information on whether someone took maternity leave. While we may miss women who had a child but did not take leave, we can still identify women who we know are "definitely a mother" and when they had a child (see in Figure 2 the share of women taking maternity leave in the first and last year of the period examined). Another drawback is that when an employee leaves the firm (which we use to define exit), we do not know whether the individual leaves the legal profession completely or whether they leave for another law firm. However, as discussed in the results section, we do have the reported reason an individual leaves the firm for a subset of the exiting sample (see Table 5).

We also merge the firm dataset to country-level measures of national culture used in other studies, which reflect society's preferences and beliefs about gender roles. However, some of these data are only available for a subset of the countries in which the firm operates.

Following studies like Guiso et al. (2008) and Fryer and Levitt (2010), we include the World Economic Forum's Global Gender Gap Index (WEF-GGI) and the WEF-GGI's sub-index on political empowerment from 2011.10 We also follow studies like Alesina and Giuliano (2010) and use measures from the World Values Survey (WVS) related to gender roles. Specifically, we rely on the waves that cover the 1999-2014 period and use the questions asking respondents to rate their agreement with the following statements on a 1-4 scale (" 1 " is Agree Strongly and "4 is

10 The WEF-GGI is based on sub-indices that measure gender differences in economic participation and opportunity, educational attainment, political empowerment, health, and survival. More information on these sub-indices and the underlying variables is available in Hausmann, Tyson and Zahidi (2011). 
Strongly Disagree) regarding housewives ("Being a housewife is just as fulfilling as working for pay"), business executives ("Men make better business executives than women do"), political leaders ("Men make better political leaders than women do"), and university education ("University is more important for a boy than for a girl"). Lower values on these questions represent more traditional roles of women in society. We create a measure of the sum of these variables that we will refer to as the 'WVS conservative values index', where lower values represent more conservative values regarding the role of women in society (see a similar approach in Alesina and Giuliano, 2010). 11 We also examined other measures used to measure progress of women in society, including the female-male ratio of enrollment in tertiary education, female labor force participation (used by e.g. Fernandez and Fogli, 2009) and the female-male ratio of members of parliament.

In order to explain the gaps we observe at the highest ranks in the firm, in our main analysis we focus on estimating the probability of promotion and exit among employees, allowing us to test for significant differences in the probabilities of each outcome for men and women. Given the panel nature of our data, which provides us with annual observations for the same employees for every year they are working in the firm, we follow other studies examining promotion probabilities and estimate probit models, where we define promotion as a binary variable equal to one if an employee moved to a higher rank the next year and zero otherwise (e.g. Blau and Devaro, 2007; McDowell, Singell and Ziliak, 1999). Exit is defined as a binary variable equal to one if an employee was no longer in the firm the next year and zero otherwise.

11 We include the following waves of the survey: 1999-2004, 2005-2009 and 2010-2014. Agreement with the statements is rated from 1 (Agree strongly) to 4 (Strongly disagree), so that higher values indicate more progressive. 
We run the models separately for each country in which the firm has an office to see if the coefficient on the female dummy is significantly different from zero, which means there is a significant gender gap. In addition to the female dummy and year dummies, we include additional variables for worker and job characteristics (age, age2, tenure in the firm, area of practice). The full specification of the probit model is as follows for individual $\mathrm{i}$, in year $\mathrm{t}$, country $\mathrm{c}$ :

$$
\begin{aligned}
& \operatorname{Pr}\left(\text { Promoted }_{\mathrm{it}+1}\right)=\Phi\left(\beta_{1} \text { Female }_{\mathrm{i}}+\beta_{2} \text { Age }_{\mathrm{it}}+\beta_{3} \text { Age }_{\mathrm{it}}^{2}+\beta_{4} \text { Tenure }_{\mathrm{it}}+\right. \\
& \left.\beta_{5} \text { Tenure }_{\mathrm{it}}^{2}+\delta_{\mathrm{c}}+\gamma_{\mathrm{t}}+\text { Female }_{\mathrm{i}} * \gamma_{\mathrm{t}}\right)
\end{aligned}
$$

where for employee $i$ working in country office $c$ in year $t$, female is a dummy for a female employee, age is measured in years (precise from HR records), tenure is defined as years in the firm. We also include a full set of time dummies using the year of the observation to account for time trends in terms of promotion probabilities within the firm, and we also interact these time dummies with the female dummy.

We are primarily interested in the coefficient on the female dummy, which will be a measure of the differential likelihood of promotion for women compared to men. We are also interested in the coefficients on the interactions of the female dummy and the year dummies, which will reflect changes in the gap over time. We run similar specifications for the outcome of exiting the firm, performance ratings and wages. All probit results presented are the marginal effects at the means of continuous variables, while for binary independent variables, they reflect predicted probabilities when the variable increases from 0 to 1.

We also run similar regressions estimated with OLS where log of wages and ratings are the dependent variables. 


\section{RESULTS}

\section{A. Recruitment}

Figure 3 shows the share of new associates female by cohort. We observe significant heterogeneity among countries in the trends from 2003-2011. In many countries, the average share of women among new attorneys has increased in the more recent cohorts with respect to the earlier ones. Also, in the majority of countries gender equality has been reached among associates in the most recent cohorts. In some of the countries with large initial gender gaps, a larger share of female attorneys at the entry-level position was hired over the years. On the other hand, following the 2008 economic downturn, in some countries no new lawyers at the entry-level position were hired in the aftermath of the financial crisis.

For example, in the largest office, the UK, the share of new associates who were female was steady around 50-60\%, but started to notably decline after 2009. In Germany, the share was quite steady over the period, but relatively low at around $40 \%$. France, meanwhile, has had a steady increase, with close to $80 \%$ of the new associates being female by 2011 . Among the emerging economies, the share of new associates who were female has been fluctuating much more, likely due to the changing business of the firm in this context. For example, in China, while there were periods where almost all new Associates were female, but the share has fluctuated considerably. Brazil and Russia also had periods with close to $80 \%$ of the new Associates being female, but then the share declined by 2010 and 2011.

In Figure 4a, we show that the share of all Associates who were female increased for most countries from 2004 to 2011, with several offices (Poland, Belgium, UK, Sweden and Hong Kong) being at $50 \%$ or above. Yet, it is clear from Figure $4 \mathrm{~b}$, that the gender gap among Partners is 
stark. Only Sweden had 50\% of Partners female in 2011, and several countries had no female partners even in 2011.

\section{B. Promotion and Exit}

Next, we investigate the gender differences further in a regression framework that allows us to control for worker characteristics and performance. First, we estimate probit models for the probability of promotion and of exit. In these models, we run separate regressions for each of the 10 country offices that meet our sample inclusion criteria of having some lawyers in each position and at least 30 associates in 2011. In these specifications, we are interested in estimating the magnitude of the difference in the probability of promotion for men and women by looking at the female coefficient and the interactions of the female dummy with the year dummies to see whether the promotion probabilities for men and women has changed over time.

Table 3 shows the results of the promotion regressions for the pooled sample of Associates and Managing Associates, which estimates the likelihood that an individual in each position in a given period is promoted to the higher rank (Managing Associate or Partner) in the next period. The regressions include the controls described in section III, including area of practice dummies as women are more heavily concentrated in some areas of practice than others12. We can see that across most countries, there is a gender gap in promotion, with men being more likely to be promoted relative to women. The exceptions are the UK and Hong Kong, where the difference is not significant, and Japan, where women are more likely to be promoted than men.

12 For example, on average, a larger share of female among attorneys works in the areas of employment and financial regulation. On the other hand, a smaller share of female is found in the areas of capital markets and mainstream corporate. The detailed figures are available from the authors upon request. 
We include an interaction of the Female dummy with a dummy for those individuals in the Associate rank to see if the gap in promotion decreases in the higher rank. This coefficient is positive is many cases, which indicates that the gender gap in promotion is smaller at the highest promotion level (from Managing Associate to Partner). Notably, in Japan, the sign is negative, which suggests that gender gap in promotion favors women relative to men at the higher rank of Managing Associate rather than at the lower rank of Associate. In the largest office, the UK, there does not appear to be a gap at either rank.

Turning to the coefficients on the Female dummies interacted with the year dummies, we can see that for several countries there do not appear to be significant changes over the period studied. However, for the countries in Columns 6-10, the coefficients on the interactions are positive and significant, indicating that the gap in promotion is declining over time.

Next, we similarly estimate the probability of exiting the firm in Table 4. In general, we do not find a significant difference between men and women in the likelihood of exit. The exceptions are Germany, where women are more likely to exit than men, and Spain, where women are less likely to exit. There do not appear to be significant differences at the higher rank, except that in Spain women at the lower rank are less likely to exit than at the higher one. The interactions suggest that in some countries (Brazil and Germany) the likelihood of women exiting has been declining over time, while in Spain it has been increasing, as well as in Russia for some years.

While this analysis suggests that men and women tend to exit at equal rates, information for a subsample of employees on why they left the firm suggests that men and women leave for different reasons. In Table 5, we group the self-reported reasons for leaving the firm into those for which the individual is "pulled up", "pulled sideways" for career reasons, "pulled sideways" for family/lifestyle reasons, "pulled down", "pushed out" and "other". The results show that 
differences between men and women are quite stark and significant for both Associates and Managing Associates: women are more likely to leave when pulled sideways for family/lifestyle reasons, and men leave when they are "pulled up" for career advancement. For Associates only, men are also more likely to leave when pulled sideways for career reasons or when pushed out.

\section{Ratings and Wages}

In order to explore a further dimension of career dynamics we also analyzed wage gaps and differences in performance ratings between men and women.

One explanation for the gender gap in promotion often suggested that women may be less productive than men. Table 6 shows the results of a regression estimating a gender gap in performance ratings across the countries in our sample. We find that in 4 of the countries (UK, Brazil, Germany and Hong Kong), there is a significant gender gap in performance ratings. The gap in the UK is smallest among the countries, with women earning on average 0.06 points lower than men. In the other countries it is larger, with the gap in Brazil 0.3 points. The interaction of the Female dummy with the Associate rank shows that in these countries, the gap is higher at the higher rank of Managing Associate.

While these results suggest that women may indeed be less productive than similar men in the firm, performance ratings are likely to be biased (e.g., Tsui and O'Really, 1989), so that it isn't clear whether this reflects productivity or whether there are biased assessments of women's performance within the firm that is captured by the rating.

In Table 7, we estimate the gender pay gap. We see that in 4 of the 10 countries in the sample, there is a gender pay gap. The gap is $4.4 \%$ in the UK and $7.5 \%$ in Germany. The largest gaps are in Spain $(24.3 \%)$ and the interaction of the female dummy with the Associate rank shows 
that this gap is larger at the lower Associate rank. Strikingly, we find that there is a significant gender pay gap in Sweden of $15.5 \%$, despite this being the office with parity in representation of women at the Partner level.

In the other countries, we do not find evidence of a significant gap, which is a finding in accordance with other findings on the lack of a gender pay gap in professional sectors, such as Gayle, Golan and Miller (2012). We note however that we have also estimated regressions using total compensation instead of only wages, which includes bonuses, and there are more significant gaps using this measure (results are available upon request).

We note that we have also examined the wage increase upon promotion for men and women. We find that men experience a wage increase of $8.7 \%$ and women of $7.4 \%$ (after including individual fixed effects). However, the difference between men and women is not significant when we run the regression on the pooled sample of men and women, which is also in line with existing research (e.g. Blau and Devaro, 2007). In light of our results on the gap in promotion probabilities, this suggests that the most significant difference is related to the career trajectories rather than compensation.

\section{Differences Across Countries}

We next examine to what extent there are differences in the promotion, exit, rating and wage gaps across countries. We saw in the earlier analysis that a gender gap in these dimensions existed even after controlling for demographic and job characteristics.

Thus, we turn to the analysis on the pooled sample. Figures $5 \mathrm{a}$ and $5 \mathrm{~b}$ present the coefficients on the female dummy interacted with the country dummies from the full specification with demographic and job characteristics using the pooled sample of all lawyers working in the 
firm across all offices. The UK is the omitted country, which is chosen both because it has the greatest number of lawyers and it is the headquarters of the firm. These coefficients reflect how much the countries differ relative to the UK in the differential promotion probabilities, exit probabilities, ratings and wages of men and women. A joint significance test for the country dummies interacted with the female dummy after the probit estimation indicates that there are significant differences in the likelihood of promotion and exit as well as in ratings and wages for women across countries.

Unlike the earlier results, these coefficients from the pooled sample show how much of the observed gap can be attributed to some characteristic of the country in which the lawyer is working in. Figure 5a displays the coefficients from female dummies interacted with the country fixed effects for the probit estimates of the probability of promotion and exit, whereas Figure 5b shows the coefficients for the OLS estimates of the ratings and wage gaps. Only a limited number of coefficients are significant at the 5\% level: the probability of leaving the law firm for women relative to men is higher in Russia, and lower in Sweden and the United States. On the other hand, gender differences in ratings are higher in Brazil and Luxembourg, while they are lower in Hong Kong and Poland. Wage differences for women relative to men are lower in Russia. The probability of promotion for women relative to men is not statistically significantly different.

Small sample sizes in some offices lead to large standard errors for many of the other coefficients. However, looking at the signs of the coefficients, it is clear that there are likely differences across countries in the promotion of women relative to men, as well as in ratings and wages that are unexplained by worker and job characteristics.

In Figure 2 we observe an important variation across offices in the share of women taking maternity leave, showing one way the country-specific context may matter for career dynamics in 
the firm. In the majority of the countries in our sample this share is below 10 percent over the period examined. An exception is represented by Sweden where the share is above 30 percent in the 2004 but declines to about 15 percent in 2011. On the other hand, the share increases from 5 to 20 percent in Russia. An analysis on the effects of maternity leave on the gender gaps goes beyond the scope of this paper, but an important direction for future research is an analysis of the interplay between firm-specific and country-level maternity leave policies and cultural factors.

Figures 2 and 5 suggest that national culture may play some role in the extent to which women are less likely to be promoted within the firm compared to men. However, as Fernandez and Fogli (2009) discuss, the country dummy coefficients from Figure 5 do not help us understand how culture matters. We next investigate these differences further by incorporating various measures of culture used in the literature in our analysis, as described in Section IV. In Figure 6, we plot the female-to-male ratio of the likelihood of promotion, exit, and log of wages for associates by country in the most recent year (2010) in our sample against different measures of culture used in the literature (the WVS Conservative Values Index, or the sum of the gender questions in the World Values Survey, as described in Section III), the female-male tertiary education enrollment ratio, and the 2011 WEF Global Gender Gap Index). The graphs suggest that for many of these measures, there appears to be a positive relationship with promotion, wages and ratings, so that countries with more gender equal attitudes tend to have more favorable labormarket outcomes for women in the firms. For example, the top left panel in Figure 6 shows that a more egalitarian view over the role of women in society based on the World Values Survey measures is associated with a higher probability for women to be promoted. The bottom middle panel shows that a higher WEF gender gap index, which measures gender equality along the health, 
education, economic and political participation dimensions, is associated with higher wages for women relative to men. is associated with higher wages for women relative to men.

Meanwhile, the relationship appears to be negative for the likelihood of women exiting the firm relative to men, as a higher female to men ratio in tertiary enrollment is correlated with a lower relative ratio of women to men leaving the firm. It is worth noting also that in the majority of countries in the analytical sample, women have higher tertiary enrollments than men.

These graphical analyses do not control for individual or country-level factors that can influence promotion. To account for these factors, Table 8 shows the results of probit regressions for promotion and exit, and OLS estimates for the ratings and wage models, after including country dummies. We include the full set of controls as before and country dummies, as well as interactions of the female dummy and measures of national culture, which were described previously. Although some of the coefficients are not precisely estimated, the results suggest that these measures of national culture do play a role in the differential likelihood of promotion of men and women. Note that since we also include the country dummy separately, this is a rather strict test, as it shows of whether our measures of national culture are capturing variation beyond what is absorbed by the country dummies.

The aggregated measure, the WEF gender gap index, is significant in the wage regression suggesting that an overall larger gender gap score is associated with higher wages for women in the firm. On the other hand, the sum of the WVS questions, is not significant. The results related to the tertiary enrollment ratio suggest that an expansion of higher education is associated with a lower probability of leaving the firm for women relative to men. The coefficients related to the probability of promotion and wages are not significant but they are positive and the standard errors are not large. The political empowerment sub-index has a positive and significant estimated 
coefficient, suggesting that greater equality in political participation is associated with higher wages for women.

\section{CONCLUSION}

Our study has provided the first analysis of gender gaps in career dynamics in the legal sector in an international context by relying on a unique individual-level dataset from a global law firm, which is consistent and comparable across a large number of countries. Our main findings show that gender gaps increase with seniority and in spite of increased gender parity at the entrylevel position, women are less likely to be promoted to more senior positions in the firm. Our analysis of the trends over time by country suggest that the gaps in promotion and exit are declining over time, but continue to persist in some countries. Importantly, we show that more women leaving the firm report leaving when 'pulled sideways' for family/lifestyle reasons, while more men report leaving when they are 'pulled up' for career reasons.

Our analysis also shows that there are cross-country differences in the likelihood of promotion for men vs. women that exist even within the same firm. While we find that a small share of the overall gap in promotion between men and women is due to these cross-country differences, we show that part of this share can be attributed to differences in the prevailing preferences and beliefs about women's role in society, or national culture. Thus, our study contributes to a growing set of studies showing that "culture matters" (along with e.g. Fernandez and Fogli, 2009). To our knowledge, this is the first study that shows culture matters in the existence of gender gaps in promotion in a professional sector. While these results do not point to why culture matters in explaining the differences in promotion among men and women, they do 
show that culture does likely play a role. Future research is needed that can pin down the mechanisms through which culture matters, such as through women's own career decisions and efforts, or through the environment and institution in which they work, such as through biased performance ratings or lack of a culture that allows women to combine family and work. 


\section{REFERENCES}

AISENBREY, S. and BRUCKNER, H. (2008), "Occupational Aspirations and the Gender Gap in Wages”, European Sociological Review, 24(5): 633-649.

ALESINA, A. GIULIANO, P. (2010), "The Power of the Family", Journal of Economic Growth, 15(2): 93-125.

"A Few Good Women", the American Lawyer, May 28, 2015

http://www.americanlawyer.com/id=1202726917646/A-Few-Good-

Women?slreturn=20150730050802

AZMAT, G. and FERRER, R., (2017) Gender Gaps in Performance: Evidence from Young Lawyers, Journal of Political Economy, 125(5): 1306-1355.

BERTRAND, M. (2011), "New Perspectives on Gender", Handbook of Labor Economics, 4: 1543-1590.

(2018), "Coase Lecture - The Glass Ceiling”, Economica, 85: 205-231.

, GOLDIN, C. and KATZ, L. (2010), "Dynamics of the Gender Gap for Young Professionals in the Financial and Corporate Sectors", American Economic Journal: Applied Economics, 2: 228-255.

and HALLOCK, K. F. (2001), "The Gender Gap in Top Corporate Jobs", Industrial and Labor Relations Review, 55(1): 3-21.

BLAU, F.D. and WINKLER, A. (2018), "The Economics of Women, Men, and Work", 8th edition, Oxford University Press.

BLAU, F.D. and DEVARO, J. (2007), "New Evidence on Gender Differences in Promotion Rates: An Empirical Analysis of a Sample of New Hires", Industrial Relations: A Journal of Economy and Society, 46(3): 511-550.

BRUSH, C.G. and BLANK, A.M. (2014) "Diana Report - Women Entrepreneurs 2014: Bridging the Gender Gap in Venture Capital", Babson College Publication

CATALYST (2013), “Catalyst Quick Take: Women in Law in the U.S.”, New York, NY: Catalyst.

COHEN, L.E., BROSCHAK, J.P. and HAVEMAN, H.A. (1998), "And Then There Were More? The Effect of Organizational Sex Composition on the Hiring and Promotion of Managers", American Sociological Review, 63(5):711-727. 
DROLSHAMMER, J.I. and M. Pfeifer (eds.) (2001), “The Internationalization of the Practice of Law", The Hague: Kluwer Law International.

EAGLY, A.H. and CARLI, L.L. (2007) "Through the Labyrinth: The Truth About How Women Become Leaders", Cambridge, MA: Harvard Business School Press.

ELVIRA, M.M. and COHEN, L.E. (2001), "Location Matters: A Cross-Level Analysis of the Effects of Organizational Sex Composition on Turnover", Academy Management Journal, 44(3): 591-605.

FERNANDEZ, R. and FOGLI, A. (2009), "Culture: An Empirical Investigation of Beliefs, Work, and Fertility", American Economic Journal: Macroeconomics, 1(1): 146-177.

"Gender Gap at Top Law Firms" Financial Times, September 7, 2008, http://www.ft.com/cms/s/0/ea929d00-7d01-11dd-8d59-000077b07658.html\#axzz1MJjAWS8W

"Why Law Firms must Change how they Work" (2019)" Financial Times, June 14, 2019, https://www.ft.com/content/81205f00-8d27-11e9-a1c1-51bf8f989972

FORTUNE (2014), "In Silicon Valley, women still a rarity in the top ranks" http://fortune.com/2014/07/08/silicon-valley-women-gender-gap/

FRYER, R.G. and LEVITT, S.D. (2010), "An Empirical Analysis of the Gender Gap in Mathematics", American Economic Journal: Applied Economics, 2(2): 210-240.

GALANTER, M. and PALAY, T. (1991), “Tournament of lawyers: The transformation of the big law firms", Chicago: University of Chicago Press.

GANGULI, I., HAUSMANN, R. and VIARENGO, M. (2018), "Career Dynamics and Gender Gaps among Employees in the Microfinance Sector," UNU-WIDER Working Paper No. 2017/117, chapter published in Anderson S., L. Beaman and J.P. Platteau (eds.), "Towards Gender Equity in Development" published by Oxford University Press.

and (2014), "Closing the Gender Gap in Education: What is the State of Gaps in Labor Force Participation for Women, Wives and Mothers?" International Labour Review, (lead article), Vol. 153, No. 2, pp. 173-208; [Harvard University, Center for International Development Working Paper No. 220].

GAYLE, G.-L., GOLAN, L. and MILLER, R.A. (2012) "Gender Differences in Executive Compensation and Job Mobility”, Journal of Labor Economics, 30(4): 829-887.

GILSON, R.J. and MNOOKIN, R.H. (1988) "Coming of Age in a Corporate Law Firm: The Economics of Associate Career Patterns”, Stanford Law Review, 41: 567-595. 
GOLDIN, C. (2014), “A Grand Gender Convergence: Its Last Chapter”, American Economic Review, 104 (4):1091-1119

(2015), “A Pollution Theory of Discrimination: Male and Female Differences in Occupations and Earnings". In: Human Capital in History: The American Record. Chicago, IL: University of Chicago Press: 313-348.

and KATZ, L.F. (2016), "A Most Egalitarian Profession: Pharmacy and the Evolution of a Family Friendly Occupation”, Journal of Labor Economics, 34 (3): 705-745.

GUISO, L., MONTE, F. , SAPIENZA, P., and ZINGALES, L. (2008), "Culture, Gender, and Math", Science, 320(5880): 1164-5.

HAUSMANN R., TYSON, L.D.A. and ZAHIDI, S. (2011). The global gender gap report 2011. Geneva: World Economic Forum.

HOFSTEDE, G.H. (1984), “Culture's Consequences: International differences in WorkRelated Values", New York, NY: SAGE Publications.

"Law Firms' Gender Diversity Programs Aren't Keeping Women in the Industry" (2017), Fortune, April 19, 2017 http://fortune.com/2017/04/19/big-law-firms-women/

LANDERS, R.M., REBITZER, J.B. and TAYLOR, L.J. (1996) "Rat Race Redux: Adverse Selection in the Determination of Work Hours in Law Firms," American Economic Review, 86(3): 329-348.

LAZEAR, E. and SHAW, K. (2007), "Personnel Economics: The Economist's View of Human Resources", Journal of Economic Perspectives, 21(4): 91-114.

“The Gender Gap goes High Tech”, Los Angeles Times, August 25, 1998, A1.

McDOWELL, J.M., JR SINGELL, L.D., and ZILIAK, J.P. (1999), "Cracks in the Glass Ceiling: Gender and Promotion in the Economics Profession, American Economic Review, 89: 392-396.

McKINSEY (2017), “Women in Law Firms”, McKinsey Publication.

MURAVYEV, A., TALAVERA, O. and Schäfer, D. (2009) "Entrepreneurs' gender and financial constraints: Evidence from international data" Journal of Comparative Economics 37: 270-286.

NATIONAL ASSOCIATION OF WOMEN LAWYERS (2014), "2014 Eighth Annual National Survey on Retention and Promotion of Women in Law Firms", Chicago, IL: The NAWL Foundation. 
NOONAN, M.C, CORCORAN, M.E. and COURANT, P.N. (2005), "Pay Differences Among the Highly Trained: Cohort Differences in the Sex Gap in Lawyers' Earnings", Social Forces, 84(2): 853-872.

O'FLAHERTY, B. and SIOW, A. (1995) "Up or Out Rules in the Market for Lawyers", Journal of Labor Economics, 13(4): 709-735.

PRITCHETT, L. and VIARENGO, M. (2010), "Explaining the Cross-National Time-Series Variation in Life Expectancy: Income, Women's Education, Shifts and What Else?" Background Paper published in the Human Development Report 2010 Twentieth Anniversary of the United Nations Development Programme (UNDP); UN Human Development Research Paper No. 2010/31.

RIKLEEN, L.S. (2013), "Solving the Law Firm Gender Gap Problem", Harvard Business Review, August 20, 2013, http://blogs.hbr.org/2013/08/solving-the-law-firm-gender-ga/

"Top Law Firms committed to Closing the Gender Gap", The Times, May 22, 2014 http://www.thetimes.co.uk/tto/law/student-law/article4096198.ece

TSUI, A.S. and O'REILLY III, C.A. (1989), "Beyond Simple Demographic Effects: The Importance of Relational Demography in Superior-Subordinate Dyads", Academy of Management Journal, 32(2): 402-423.

"Female Lawyers Still Battle Gender Bias - Despite Advances, Women Still Lag Behind Men in Billing Rate, Management Roles" Wall Street Journal, May 4, 2014, http://www.wsj.com/articles/SB10001424052702303948104579537814028747376

WOLFERS, J. (2006), “Diagnosing Discrimination: Stock Returns and CEO Gender”, Journal of the European Economic Association, 4(2-3): 531-541.

WOOD, R.G., CORCORAN M.E., and COURANT, P.N. (1993), "Pay Differences among the Highly Paid: The Male-Female Earnings Gap in Lawyers' Salaries” Journal of Labor Economics, 11(3): 417-441. 


\section{Tables and Figures}

Figure 1: Hierarchy of Ranks: Career Legal Paths within the Law Firm

\begin{tabular}{|c|l|l|l|l|l|}
\hline Years in Firm & Asia & $\begin{array}{l}\text { Middle } \\
\text { East }\end{array}$ & Europe & $\begin{array}{l}\text { Latin } \\
\text { America }\end{array}$ & $\begin{array}{l}\text { North } \\
\text { America }\end{array}$ \\
\hline $\mathbf{1 0 +}$ & & & & & \\
\hline $\mathbf{9}$ & & & & & \\
\hline $\mathbf{8}$ & & & & & \\
\hline $\mathbf{7}$ & & & & & \\
\hline $\mathbf{6}$ & & & & & \\
\hline $\mathbf{5}$ & & & & & \\
\hline $\mathbf{4}$ & & & & & \\
\hline $\mathbf{5}$ & & & & & \\
\hline $\mathbf{4}$ & & & & & \\
\hline $\mathbf{3}$ & & & & & \\
\hline $\mathbf{2}$ & & & & & \\
\hline $\mathbf{1}$ & & & & & \\
\hline
\end{tabular}

\section{Legend \\ Associate \\ Managing \\ Associate \\ Partner (eligibility)}

Note: The region classification is presented in Table 1. Specific information related to the career legal path for each country in the five geographic regions is available from the authors. 
Figure 2: Share of women employees taking maternity leave

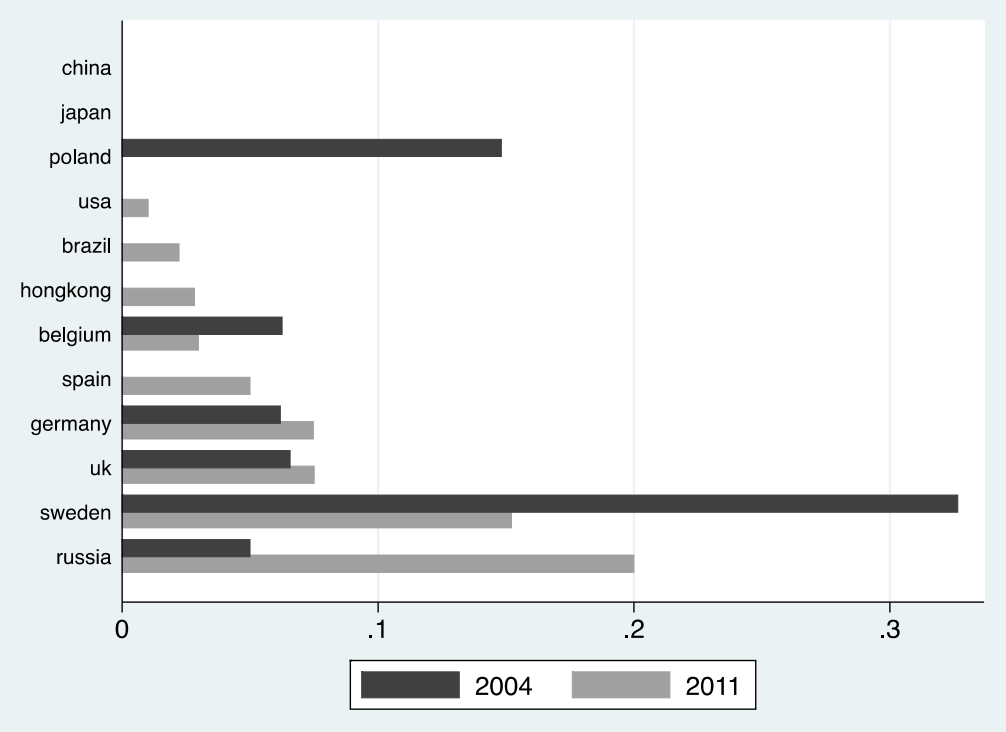


Figure 3: Recruiting: Share of New Associates Female, by Cohort

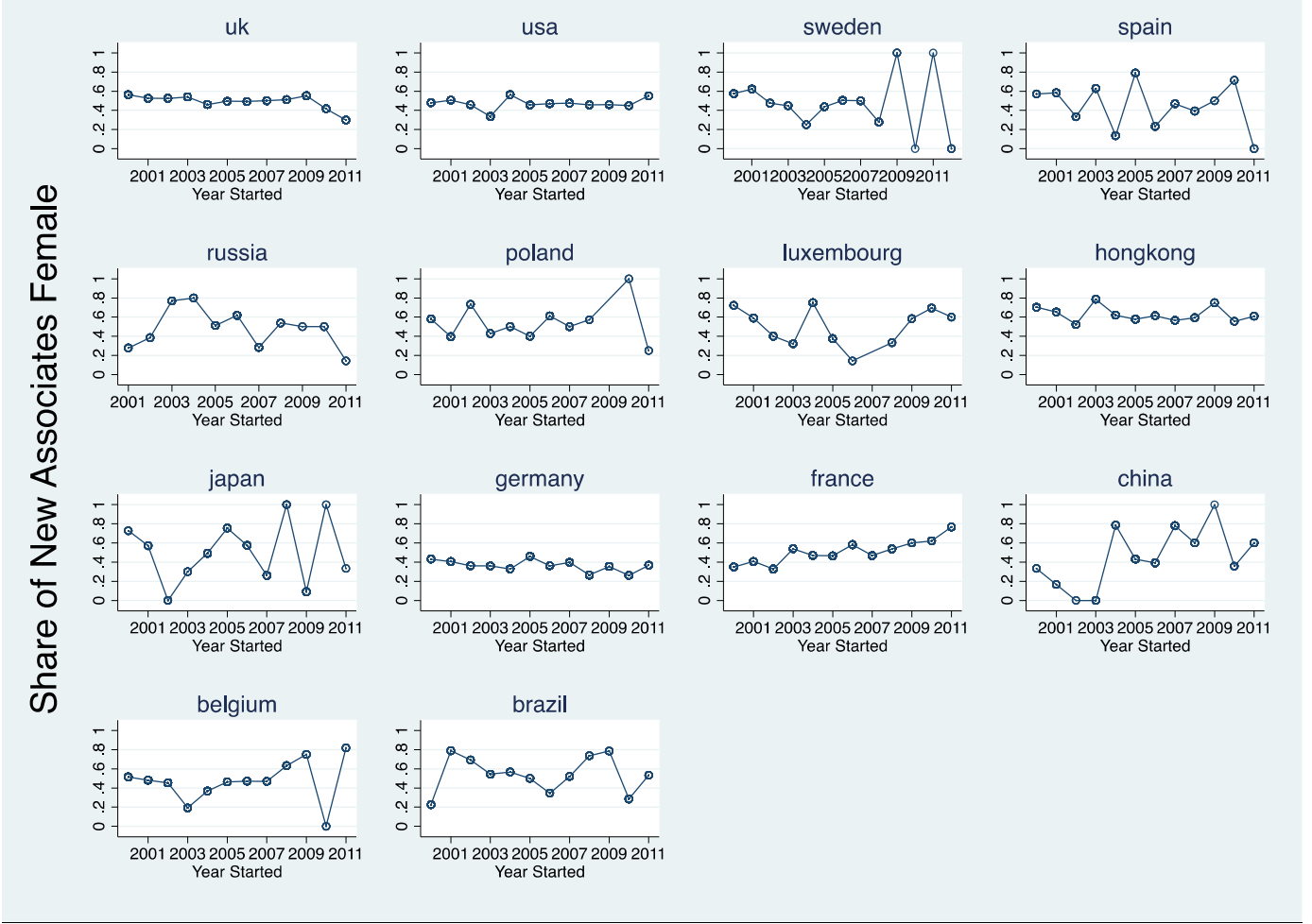

Notes: In addition to the 10 countries with lawyers in each position and at least 30 associates in 2011 included in our main analysis, here we include an additional 4 countries that do not have lawyers in every position. 
Figure 4a: Share of Associates Female

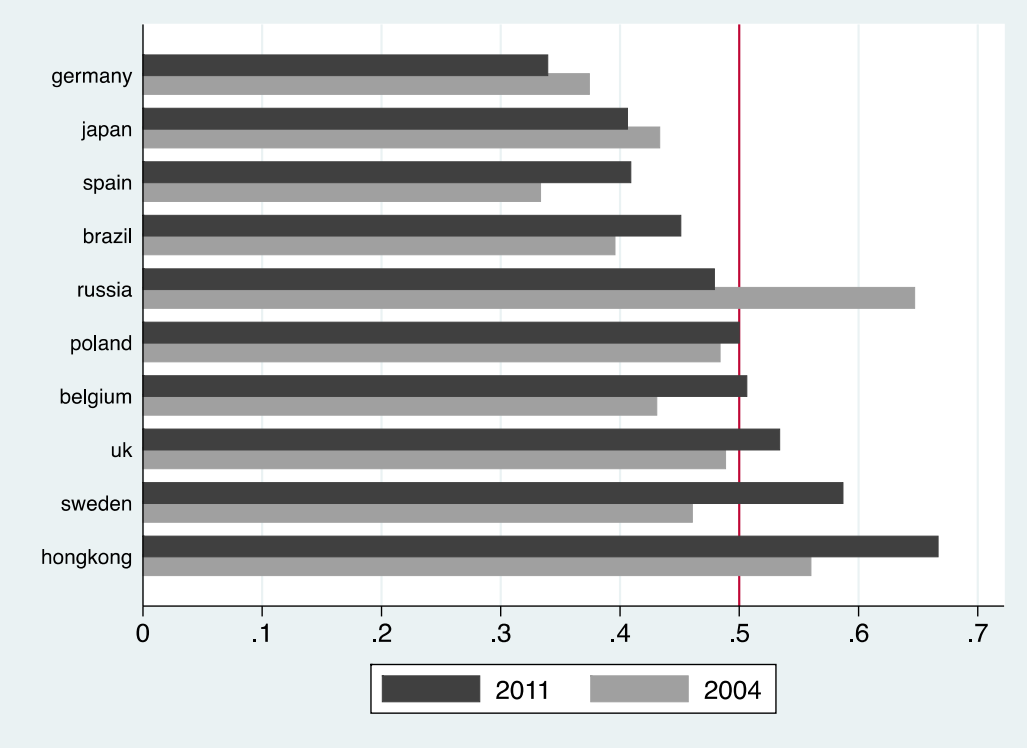

Figure 4b: Share of Partners Female

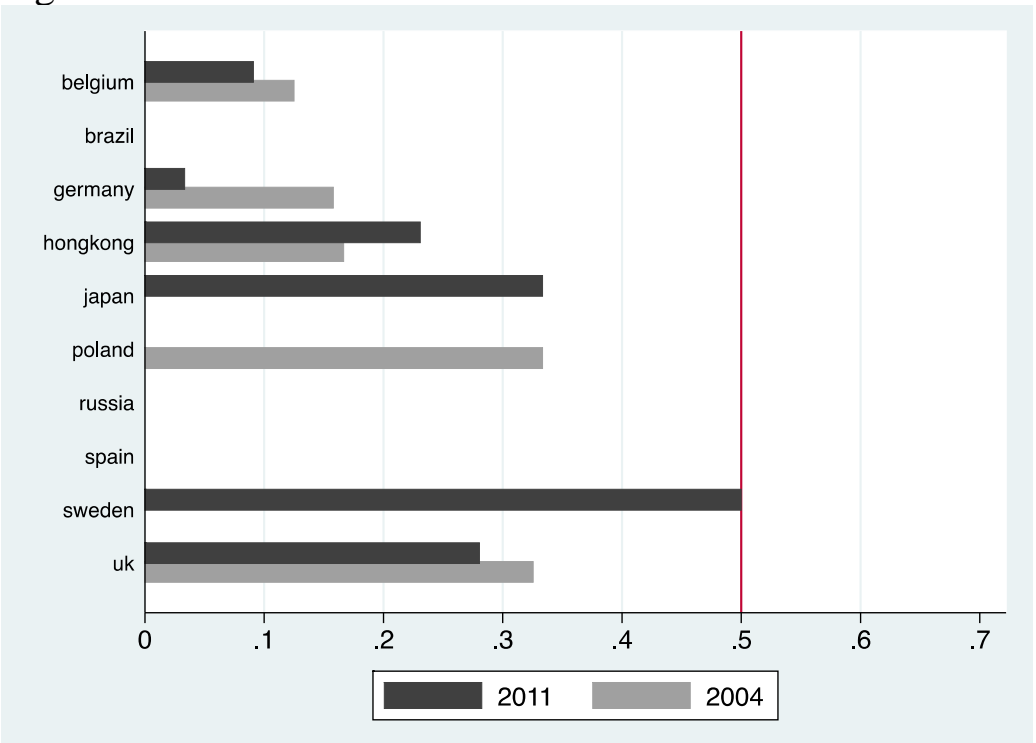


Figure 5a: Probability of Promotion and Exit: Female x Country Fixed Effects

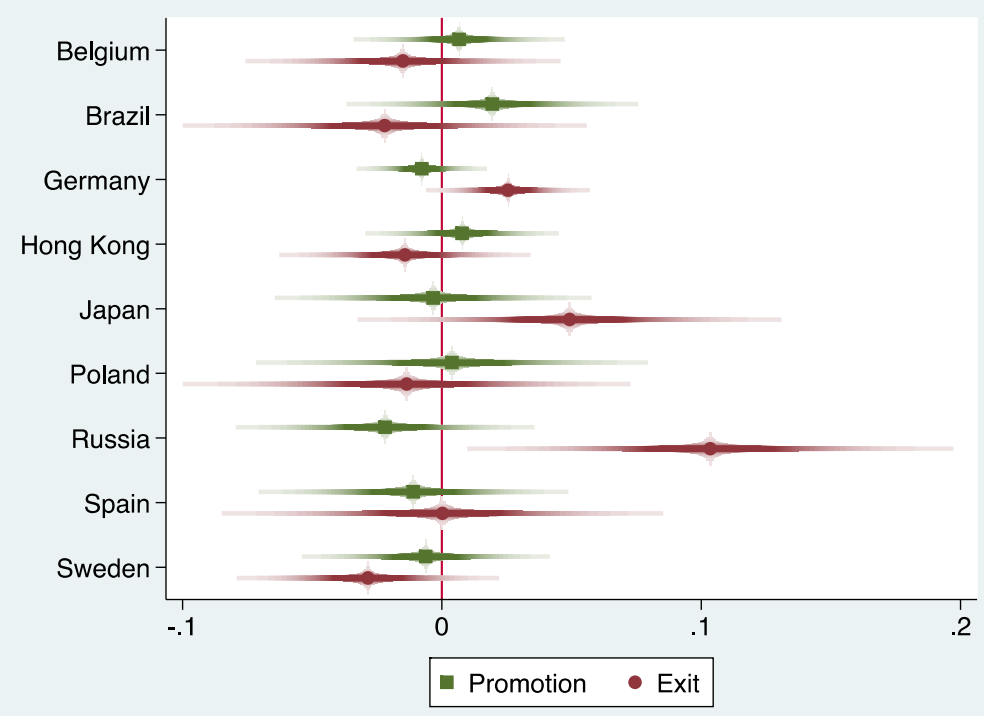

Notes: Marginal effects from probit estimates of the probability of promotion and exit for the female dummy interacted with the specified country fixed effect for Associates only. UK is omitted. Plots show smoothed confidence intervals for 50 equally spaced levels from 1 to 99.

Figure 5b: Ratings and Log Wages: Female x Country Fixed Effects

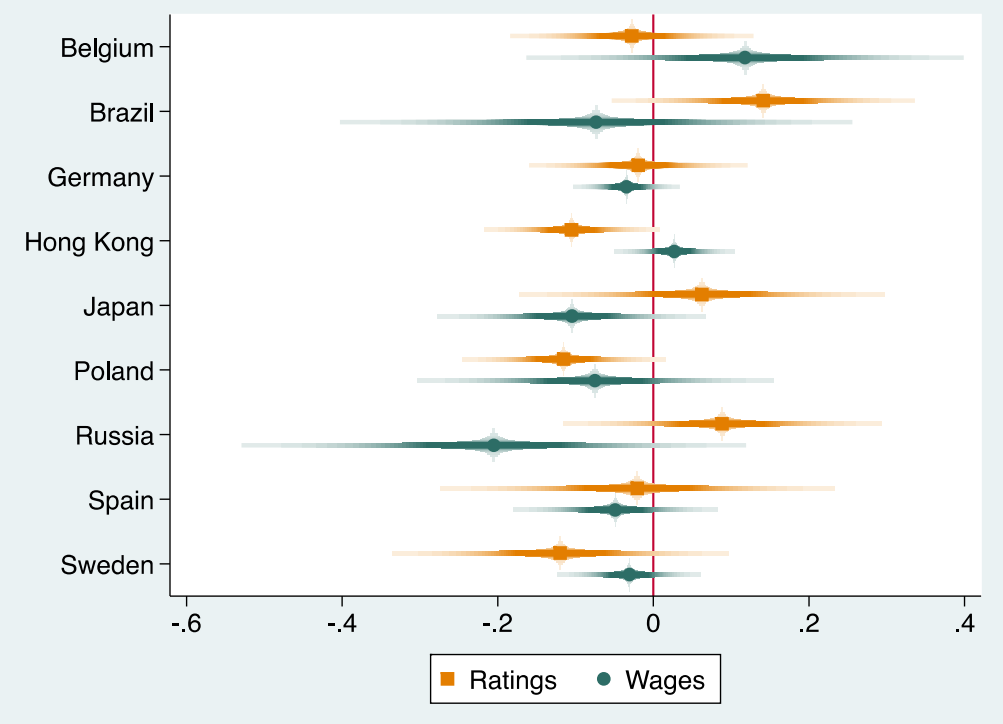

Notes: OLS estimates from ratings and wage regressions for the female dummy interacted with the specified country fixed effect for Associates only. UK is omitted. Plots show smoothed confidence intervals for 50 equally spaced levels from 1 to 99 . 
Figure 6: Female-Male Ratio of Promotions, Exits and Wages (2010) vs. Measures of Culture
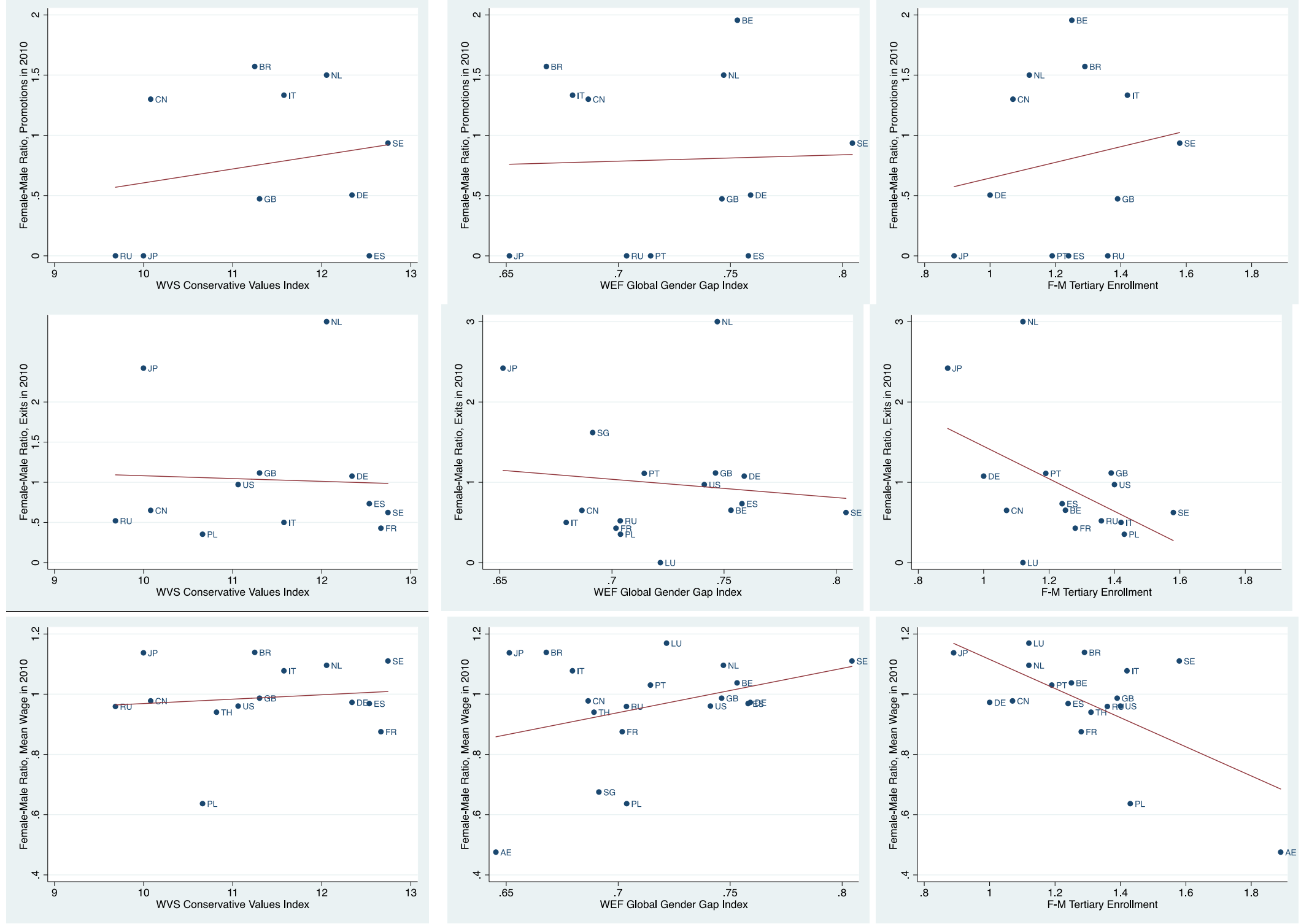
Notes: "WVS Conservative Values Index" is the country average of the sum of individual respondents' agreement with the following statements, where "1" is Agree Strongly and "4" is Strongly Disagree, i.e. lower values represent more conservative roles of women in society: "Being a housewife is just as fulfilling as working for pay", "Men make better business executives than women do", "Men make better political leaders than women do" and "University is more important for a boy than for a girl". "The WEF Global Gender Gap Index" is based on the World Economic Forum's 2011 Global Gender Gap Index, where the subindices measure gender differences in economic participation and opportunity, educational attainment, political empowerment, health, and survival, so that higher values mean smaller differences between men and women. "F-M Tertiary Enrollment" is the ratio of female to male enrollment in tertiary education in 2011. 
Table 1: Lawyers by Office and Gender Composition, 2003-11

\begin{tabular}{|c|c|c|c|}
\hline Region & Country & $\begin{array}{l}\text { Number of } \\
\text { Lawyers }\end{array}$ & $\begin{array}{l}\text { Share of } \\
\text { Female } \\
\text { Lawyers }\end{array}$ \\
\hline \multirow[t]{5}{*}{ Asia } & China & 135 & 53.69 \\
\hline & Hong Kong 13 & 321 & 57.94 \\
\hline & Japan & 97 & 43.30 \\
\hline & Singapore & 60 & 51.67 \\
\hline & Thailand & 52 & 55.77 \\
\hline Middle East & United Arab Emirates & 27 & 37.04 \\
\hline \multirow[t]{16}{*}{ Europe } & Belgium & 262 & 43.89 \\
\hline & Czech Republic & 95 & 51.58 \\
\hline & France & 373 & 52.01 \\
\hline & Germany & 619 & 33.60 \\
\hline & Hungary & 2 & 50.00 \\
\hline & Italy & 58 & 41.67 \\
\hline & Luxembourg & 112 & 53.57 \\
\hline & Netherlands & 79 & 34.18 \\
\hline & Poland & 110 & 49.09 \\
\hline & Portugal & 61 & 44.26 \\
\hline & Romania & 47 & 36.17 \\
\hline & Russia & 123 & 46.34 \\
\hline & Slovakia & 34 & 35.29 \\
\hline & Spain & 159 & 40.25 \\
\hline & Sweden & 248 & 41.13 \\
\hline & United Kingdom & 2,642 & 47.99 \\
\hline Latin America & Brazil & 165 & 43.64 \\
\hline North America & United States & 417 & 42.93 \\
\hline Total & & 6,585 & 46.07 \\
\hline
\end{tabular}

Notes: For the main analysis, we include 10 countries, as they have lawyers in each position and at least 30 associates in 2011(i.e., Brazil, Germany, Hong Kong, Japan, Luxembourg, Poland, Russia, Spain, Sweden and the United Kingdom). For the entry cohort graphs we include 4 additional countries which do not have lawyers in every position (i.e., China, France, Luxembourg and the United States).

13 During the period examined Hong Kong is a Special Administrative Region of the People's Republic of China. Given its status of autonomous territory, for the purpose of the analysis, Hong Kong will be examined separately from mainland China. 
Table 2: Characteristics of Lawyers by Position, 2003 and 2010

\begin{tabular}{|c|c|c|c|c|c|c|c|c|c|c|}
\hline \multirow{3}{*}{ Rank } & \multicolumn{10}{|c|}{2003} \\
\hline & \multirow[t]{2}{*}{$\mathrm{N}$} & \multirow[t]{2}{*}{$\%$ Female } & \multicolumn{2}{|c|}{$\%$ Promoted } & \multicolumn{2}{|c|}{ Age } & \multicolumn{2}{|c|}{ Tenure } & \multicolumn{2}{|c|}{$\begin{array}{l}\text { Performance } \\
\text { Rating }\end{array}$} \\
\hline & & & Male & Female & Male & Female & Male & Female & Male & Female \\
\hline Associate & 1276 & 44.51 & 0.10 & 0.05 & 29.59 & 29.18 & 2.38 & 2.60 & 3.44 & 3.42 \\
\hline Managing & & & & & & & & & & \\
\hline Associate & 463 & 35.64 & 0.06 & 0.04 & 34.55 & 33.33 & 4.69 & 4.94 & 3.68 & 3.63 \\
\hline \multirow[t]{2}{*}{ Partner } & 53 & 22.64 & & & 41.17 & 39.33 & 11.15 & 11.50 & & \\
\hline & \multicolumn{10}{|c|}{2010} \\
\hline \multirow[t]{2}{*}{ Rank } & \multirow[t]{2}{*}{$\mathrm{N}$} & \multirow[t]{2}{*}{$\%$ Female } & \multicolumn{2}{|c|}{$\%$ Promoted } & \multicolumn{2}{|c|}{ Age } & \multicolumn{2}{|c|}{ Tenure } & \multicolumn{2}{|c|}{$\begin{array}{l}\text { Performance } \\
\text { Rating }\end{array}$} \\
\hline & & & Male & Female & Male & Female & Male & Female & Male & Female \\
\hline $\begin{array}{l}\text { Associate } \\
\text { Managing }\end{array}$ & 1912 & 50.84 & 0.08 & 0.04 & 30.68 & 30.50 & 3.37 & 3.63 & 3.00 & 2.92 \\
\hline Associate & 768 & 41.67 & 0.02 & 0.01 & 34.81 & 34.42 & 6.18 & 6.40 & 3.43 & 3.28 \\
\hline Partner & 268 & 23.88 & & & 42.90 & 40.36 & 11.79 & 10.86 & & \\
\hline
\end{tabular}

Notes: The employee's performance rating is based on a 4-point scale for which each level corresponds to a clear definition of performance (performance level 4 being the top rank vs. performance level 1 being the bottom one). 
Table 3: Probability of Promotion

\begin{tabular}{|c|c|c|c|c|c|c|c|c|c|c|}
\hline Promote & $\begin{array}{l}(1) \\
\text { UK } \\
\end{array}$ & $\begin{array}{c}(2) \\
\text { Belgium } \\
\end{array}$ & $\begin{array}{c}(3) \\
\text { Brazil } \\
\end{array}$ & $\begin{array}{c}(4) \\
\text { Germany } \\
\end{array}$ & $\begin{array}{c}(5) \\
\text { Hong Kong } \\
\end{array}$ & $\begin{array}{c}(6) \\
\text { Japan } \\
\end{array}$ & $\begin{array}{c}(7) \\
\text { Poland } \\
\end{array}$ & $\begin{array}{r}(8) \\
\text { Russia } \\
\end{array}$ & $\begin{array}{r}(9) \\
\text { Spain } \\
\end{array}$ & $\begin{array}{c}(10) \\
\text { Sweden } \\
\end{array}$ \\
\hline \multirow[t]{2}{*}{ Female } & -0.0330 & $-0.376^{* * *}$ & $-0.383 * * *$ & $-0.140 * *$ & -0.0172 & $0.332 * * *$ & $-1.125^{* * *}$ & $-0.534 * * *$ & $-1.219 * * *$ & $-0.352 * * *$ \\
\hline & $(0.0226)$ & $(0.0738)$ & $(0.0802)$ & $(0.0601)$ & $(0.0900)$ & $(0.124)$ & $(0.281)$ & $(0.122)$ & $(0.217)$ & $(0.0723)$ \\
\hline \multicolumn{11}{|c|}{ Female x Associate } \\
\hline \multirow[t]{2}{*}{ Rank } & -0.00317 & $0.338 * * *$ & $0.401 * * *$ & $0.0858 *$ & 0.0403 & $-0.728 * * *$ & $0.533 * *$ & $0.388 * * *$ & $0.634 * * *$ & -0.0126 \\
\hline & $(0.0152)$ & $(0.0586)$ & $(0.0632)$ & $(0.0521)$ & $(0.0619)$ & $(0.135)$ & $(0.210)$ & $(0.0974)$ & $(0.111)$ & $(0.0511)$ \\
\hline \multirow[t]{2}{*}{ Age } & $0.169 * * *$ & $0.152^{*}$ & $0.437 * * *$ & $0.212 * * *$ & $0.0177 * * *$ & $0.521 * * *$ & 0.0179 & $0.288 * * *$ & $0.291 * * *$ & -0.00929 \\
\hline & $(0.0378)$ & $(0.0826)$ & $(0.113)$ & $(0.0496)$ & $(0.00622)$ & $(0.0760)$ & $(0.0110)$ & $(0.110)$ & $(0.0962)$ & $(0.0144)$ \\
\hline \multirow[t]{2}{*}{ Age2 } & $-0.00253^{* * *}$ & $-0.00239^{*}$ & $-0.00690 * * *$ & $-0.00309 * * *$ & $0.000131 * * *$ & $-0.00783^{* * *}$ & -0.000123 & $-0.00495 * *$ & $-0.00437 * * *$ & $4.71 \mathrm{e}-05$ \\
\hline & $(0.000617)$ & $(0.00139)$ & $(0.00187)$ & $(0.000755)$ & $(4.87 \mathrm{e}-05)$ & $(0.00119)$ & $(7.92 \mathrm{e}-05)$ & $(0.00200)$ & $(0.00148)$ & $(0.000192)$ \\
\hline \multirow[t]{2}{*}{ Tenure } & 0.00147 & $0.0912 * * *$ & 0.00687 & 0.00978 & -0.00533 & $-0.0704 * * *$ & 0.0103 & 0.0174 & $-0.0383 * * *$ & $0.0836 * * *$ \\
\hline & $(0.00318)$ & $(0.0202)$ & $(0.0111)$ & $(0.00761)$ & $(0.00528)$ & $(0.0196)$ & $(0.0259)$ & $(0.0134)$ & $(0.0109)$ & $\begin{array}{l}(0.0212) \\
-\end{array}$ \\
\hline \multirow{2}{*}{ Tenure2 } & 0.000534 & $-0.0109 * * *$ & -0.000877 & 0.000546 & $0.00170 * *$ & $0.0122 * * *$ & 0.000195 & -0.000900 & $0.00435^{* * *}$ & $0.00596^{* * *}$ \\
\hline & $(0.000326)$ & $(0.00223)$ & $(0.00115)$ & $(0.00106)$ & $(0.000755)$ & $(0.00300)$ & $(0.00243)$ & $(0.00143)$ & $(0.00133)$ & $(0.00189)$ \\
\hline \multirow[t]{2}{*}{ Female x 2004} & 0.0135 & & & 0.0435 & & $0.370 * * *$ & & $0.635^{* * *}$ & $0.717 * * *$ & $0.311 * * *$ \\
\hline & $(0.0239)$ & & & $(0.0483)$ & & $(0.0843)$ & & $(0.121)$ & $(0.165)$ & $(0.0612)$ \\
\hline \multirow[t]{2}{*}{ Female x 2005} & -0.00160 & & 0.0347 & -0.0521 & -0.107 & $0.290 * * *$ & & $0.165^{*}$ & $0.537 * * *$ & $0.323 * * *$ \\
\hline & $(0.0245)$ & & $(0.0603)$ & $(0.0557)$ & $(0.0887)$ & $(0.0774)$ & & $(0.0976)$ & $(0.140)$ & $(0.0631)$ \\
\hline \multirow[t]{2}{*}{ Female x 2006} & 0.0128 & 0.0172 & 0.0711 & 0.0303 & -0.0550 & $0.330 * * *$ & & & $0.629 * * *$ & $0.323 * * *$ \\
\hline & $(0.0236)$ & $(0.0512)$ & $(0.0597)$ & $(0.0538)$ & $(0.0953)$ & $(0.0985)$ & & & $(0.153)$ & $(0.0728)$ \\
\hline \multirow[t]{2}{*}{ Female x 2007} & 0.0113 & 0.0435 & & 0.0235 & -0.0465 & & $0.661 * * *$ & 0.0667 & & \\
\hline & $(0.0233)$ & $(0.0538)$ & & $(0.0466)$ & $(0.0825)$ & & $(0.149)$ & $(0.0918)$ & & \\
\hline \multirow[t]{2}{*}{ Female x 2008} & 0.0162 & 0.0447 & 0.0302 & -0.0104 & 0.000524 & & & & $0.603 * * *$ & $0.362 * * *$ \\
\hline & $(0.0239)$ & $(0.0560)$ & $(0.0613)$ & $(0.0512)$ & $(0.0786)$ & & & & $(0.161)$ & $(0.0708)$ \\
\hline \multirow[t]{2}{*}{ Female x 2009} & 0.00349 & -0.00760 & 0.0236 & $0.121 * *$ & 0.0109 & & & 0.0727 & $1.185^{* * *}$ & $0.356 * * *$ \\
\hline & $(0.0240)$ & $(0.0573)$ & $(0.0661)$ & $(0.0480)$ & $(0.0799)$ & & & $(0.0985)$ & $(0.197)$ & $(0.0656)$ \\
\hline \multirow[t]{2}{*}{ Female x 2010} & -0.0121 & 0.0820 & 0.0193 & -0.00821 & -0.0723 & & $1.056^{* * *}$ & & & $0.344 * * *$ \\
\hline & $(0.0257)$ & $(0.0725)$ & $(0.0751)$ & $(0.0531)$ & $(0.0804)$ & & $(0.230)$ & & & $(0.0770)$ \\
\hline
\end{tabular}


Associate Rank

Dummy

Dummies

$\begin{array}{cccc}\text { Yes } & \text { Yes } & \text { Yes } & \text { Yes } \\ \text { Yes } & \text { Yes } & \text { Yes } & \text { Yes } \\ \text { Yes } & \text { Yes } & \text { Yes } & \text { Yes } \\ 7,636 & 844 & 423 & 2,447\end{array}$

$\begin{array}{ll}\text { Yes } & \text { Y } \\ \text { Yes } & \text { Yes } \\ \text { Yes } & \text { Yes } \\ 247 & 750\end{array}$

Yes Yes

Yes

Yes

Yes

Yes

Year Dummies

Yes Yes

Yes

Yes

Yes

Yes

\begin{tabular}{l}
750 \\
\hline
\end{tabular}

Yes

Yes

Yes

Yes

Yes

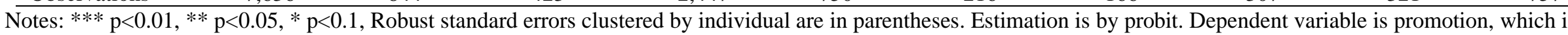

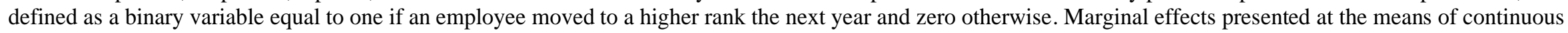
variables. For binary independent variables, marginal effects reflect predicted probabilities when the variable increases from 0 to 1. 
Table 4: Probability of Exit

\begin{tabular}{|c|c|c|c|c|c|c|c|c|c|c|}
\hline Exit & $\begin{array}{l}(1) \\
\text { UK }\end{array}$ & $\begin{array}{c}(2) \\
\text { Belgium } \\
\end{array}$ & $\begin{array}{c}(3) \\
\text { Brazil }\end{array}$ & $\begin{array}{c}(4) \\
\text { Germany } \\
\end{array}$ & $\begin{array}{c}(5) \\
\text { Hong Kong }\end{array}$ & $\begin{array}{c}(6) \\
\text { Japan }\end{array}$ & $\begin{array}{c}(7) \\
\text { Poland } \\
\end{array}$ & $\begin{array}{c}(8) \\
\text { Russia } \\
\end{array}$ & $\begin{array}{c}(9) \\
\text { Spain } \\
\end{array}$ & $\begin{array}{c}(10) \\
\text { Sweden } \\
\end{array}$ \\
\hline Female & $\begin{array}{l}-0.00376 \\
(0.0265)\end{array}$ & $\begin{array}{l}-0.101 \\
(0.0623)\end{array}$ & $\begin{array}{l}0.100 \\
(0.104)\end{array}$ & $\begin{array}{l}0.108^{*} \\
(0.0572)\end{array}$ & $\begin{array}{l}0.00490 \\
(0.0844)\end{array}$ & $\begin{array}{l}0.0317 \\
(0.0453)\end{array}$ & $\begin{array}{l}0.0531 \\
(0.123)\end{array}$ & $\begin{array}{l}0.0269 \\
(0.0628)\end{array}$ & $\begin{array}{l}-0.931 * * * \\
(0.126)\end{array}$ & $\begin{array}{l}-0.0136 \\
(0.105)\end{array}$ \\
\hline $\begin{array}{l}\text { Female x Associate } \\
\text { Rank }\end{array}$ & $\begin{array}{l}0.0143 \\
(0.0140)\end{array}$ & $\begin{array}{l}0.0778 \\
(0.0481)\end{array}$ & $\begin{array}{l}0.00322 \\
(0.0640)\end{array}$ & $\begin{array}{l}-0.0196 \\
(0.0250)\end{array}$ & $\begin{array}{l}0.00585 \\
(0.0424)\end{array}$ & $\begin{array}{l}-0.0218 \\
(0.0581)\end{array}$ & $\begin{array}{l}0.0264 \\
(0.0706)\end{array}$ & $\begin{array}{l}-0.00580 \\
(0.0550)\end{array}$ & $\begin{array}{l}-0.120 * \\
(0.0643)\end{array}$ & $\begin{array}{l}-0.0561 \\
(0.0692)\end{array}$ \\
\hline Age & $\begin{array}{l}0.0475^{* * * *} \\
(0.0123)\end{array}$ & $\begin{array}{l}0.0478 \\
(0.0327)\end{array}$ & $\begin{array}{l}0.00403 \\
(0.0187)\end{array}$ & $\begin{array}{l}-0.0241 \\
(0.0268)\end{array}$ & $\begin{array}{l}0.0171 * * \\
(0.00741)\end{array}$ & $\begin{array}{l}0.000618 \\
(0.00815)\end{array}$ & $\begin{array}{l}0.0260 * * * \\
(0.00768)\end{array}$ & $\begin{array}{l}0.0303 \\
(0.0326)\end{array}$ & $\begin{array}{l}0.0116 \\
(0.00757)\end{array}$ & $\begin{array}{l}0.0323^{* * *} \\
(0.0125)\end{array}$ \\
\hline Age2 & $\begin{array}{l}-0.000546 * * * \\
(0.000180)\end{array}$ & $\begin{array}{l}-0.000635 \\
(0.000516)\end{array}$ & $\begin{array}{l}-0.000197 \\
(0.000246)\end{array}$ & $\begin{array}{l}0.000393 \\
(0.000375)\end{array}$ & $\begin{array}{l}-0.000138^{* *} \\
(6.08 \mathrm{e}-05)\end{array}$ & $\begin{array}{l}1.08 \mathrm{e}-05 \\
(5.98 \mathrm{e}-05)\end{array}$ & $\begin{array}{l}-0.000197 * * * \\
(5.73 \mathrm{e}-05)\end{array}$ & $\begin{array}{l}-0.000339 \\
(0.000549)\end{array}$ & $\begin{array}{l}-6.39 e-05 \\
(5.47 e-05)\end{array}$ & $\begin{array}{l}0.000417^{* * *} \\
(0.000137)\end{array}$ \\
\hline Tenure & $\begin{array}{l}0.0363 * * * \\
(0.00441)\end{array}$ & $\begin{array}{l}0.0201 * \\
(0.0116)\end{array}$ & $\begin{array}{l}0.0308^{* * *} \\
(0.0107)\end{array}$ & $\begin{array}{l}0.0728 * * * \\
(0.00821)\end{array}$ & $\begin{array}{l}0.0419 * * * \\
(0.0105)\end{array}$ & $\begin{array}{l}0.0203 \\
(0.0148)\end{array}$ & $\begin{array}{l}0.00762 \\
(0.0135)\end{array}$ & $\begin{array}{l}0.0285 * * \\
(0.0120)\end{array}$ & $\begin{array}{l}0.0829 * * * \\
(0.0199)\end{array}$ & $\begin{array}{l}0.0125 \\
(0.00947)\end{array}$ \\
\hline Tenure2 & $\begin{array}{l}-0.00329 * * * \\
(0.000439)\end{array}$ & $\begin{array}{l}-0.00335 * * * \\
(0.00118)\end{array}$ & $\begin{array}{l}-0.00227 * * \\
(0.00108)\end{array}$ & $\begin{array}{l}-0.00609 * * * \\
(0.000878)\end{array}$ & $\begin{array}{l}-0.00270 * * \\
(0.00106)\end{array}$ & $\begin{array}{l}-0.00213 \\
(0.00155)\end{array}$ & $\begin{array}{l}8.60 \mathrm{e}-05 \\
(0.00111)\end{array}$ & $\begin{array}{l}-0.00210 * * \\
(0.000961)\end{array}$ & $\begin{array}{l}-0.00871 * * * \\
(0.00231)\end{array}$ & $\begin{array}{l}1.94 \mathrm{e}-06 \\
(0.000282)\end{array}$ \\
\hline Female x 2004 & $\begin{array}{l}-0.00321 \\
(0.0383)\end{array}$ & $\begin{array}{l}0.102 \\
(0.0800)\end{array}$ & $\begin{array}{l}-0.169 \\
(0.149)\end{array}$ & $\begin{array}{l}-0.0684 \\
(0.0744)\end{array}$ & $\begin{array}{l}-0.0259 \\
(0.122)\end{array}$ & $\begin{array}{l}0.738 * * * \\
(0.107)\end{array}$ & $\begin{array}{l}-0.150 \\
(0.151)\end{array}$ & $\begin{array}{l}0.644 * * * \\
(0.127)\end{array}$ & $\begin{array}{l}0.906 * * * \\
(0.150)\end{array}$ & $\begin{array}{l}0.112 \\
(0.120)\end{array}$ \\
\hline Female x 2005 & $\begin{array}{l}-0.0365 \\
(0.0338)\end{array}$ & $\begin{array}{l}0.0137 \\
(0.0798)\end{array}$ & & $\begin{array}{l}-0.0914 \\
(0.0685)\end{array}$ & $\begin{array}{l}0.0992 \\
(0.114)\end{array}$ & $\begin{array}{l}-0.0888 \\
(0.0899)\end{array}$ & $\begin{array}{l}0.0369 \\
(0.145)\end{array}$ & $\begin{array}{l}0.595 * * * \\
(0.121)\end{array}$ & $\begin{array}{l}0.783 * * * \\
(0.156)\end{array}$ & $\begin{array}{l}0.0751 \\
(0.107)\end{array}$ \\
\hline Female x 2006 & $\begin{array}{l}0.0374 \\
(0.0327)\end{array}$ & & $\begin{array}{l}-0.266^{* *} \\
(0.121)\end{array}$ & $\begin{array}{l}-0.0728 \\
(0.0654)\end{array}$ & $\begin{array}{l}-0.0999 \\
(0.114)\end{array}$ & $\begin{array}{l}0.0415 \\
(0.0816)\end{array}$ & $\begin{array}{l}-0.101 \\
(0.161)\end{array}$ & $\begin{array}{l}0.0486 \\
(0.0889)\end{array}$ & $\begin{array}{l}1.024 * * * \\
(0.134)\end{array}$ & $\begin{array}{l}0.0238 \\
(0.130)\end{array}$ \\
\hline Female x 2007 & $\begin{array}{l}0.0184 \\
(0.0335)\end{array}$ & $\begin{array}{l}-0.0436 \\
(0.0754)\end{array}$ & $\begin{array}{l}-0.0840 \\
(0.118)\end{array}$ & $\begin{array}{l}-0.0602 \\
(0.0651)\end{array}$ & $\begin{array}{l}0.0689 \\
(0.106)\end{array}$ & $\begin{array}{l}-0.104 \\
(0.0970)\end{array}$ & $\begin{array}{l}-0.144 \\
(0.138)\end{array}$ & $\begin{array}{l}0.129 * \\
(0.0722)\end{array}$ & $\begin{array}{l}1.082 * * * \\
(0.165)\end{array}$ & $\begin{array}{l}-0.0142 \\
(0.122)\end{array}$ \\
\hline Female x 2008 & $\begin{array}{l}0.00394 \\
(0.0339)\end{array}$ & $\begin{array}{l}0.0392 \\
(0.0680)\end{array}$ & $\begin{array}{l}-0.242^{*} \\
(0.126)\end{array}$ & $\begin{array}{l}-0.111^{*} \\
(0.0651)\end{array}$ & $\begin{array}{l}-0.135 \\
(0.112)\end{array}$ & $\begin{array}{l}-0.0973 \\
(0.0833)\end{array}$ & $\begin{array}{l}-0.114 \\
(0.138)\end{array}$ & $\begin{array}{l}0.595 * * * \\
(0.116)\end{array}$ & $\begin{array}{l}1.012 * * * \\
(0.153)\end{array}$ & $\begin{array}{l}-0.139 \\
(0.124)\end{array}$ \\
\hline Female x 2009 & $\begin{array}{l}-0.0332 \\
(0.0332)\end{array}$ & $\begin{array}{l}0.102 \\
(0.0680)\end{array}$ & $\begin{array}{l}-0.152 \\
(0.142)\end{array}$ & $\begin{array}{l}-0.0466 \\
(0.0684)\end{array}$ & $\begin{array}{l}-0.0549 \\
(0.108)\end{array}$ & $\begin{array}{l}0.143^{* *} \\
(0.0721)\end{array}$ & $\begin{array}{l}-0.0856 \\
(0.137)\end{array}$ & $\begin{array}{l}0.0268 \\
(0.0614)\end{array}$ & $\begin{array}{l}1.076 * * * \\
(0.149)\end{array}$ & $\begin{array}{l}0.0309 \\
(0.115)\end{array}$ \\
\hline Female x 2010 & $\begin{array}{l}0.0121 \\
(0.0337)\end{array}$ & $\begin{array}{l}-0.0409 \\
(0.0760)\end{array}$ & $\begin{array}{l}-0.160 \\
(0.168)\end{array}$ & $\begin{array}{l}-0.117 * \\
(0.0705)\end{array}$ & $\begin{array}{l}-0.00632 \\
(0.109)\end{array}$ & $\begin{array}{l}0.0551 \\
(0.0801)\end{array}$ & $\begin{array}{l}-0.149 \\
(0.142)\end{array}$ & $\begin{array}{l}-0.0925 \\
(0.0907)\end{array}$ & $\begin{array}{l}1.119 * * * \\
(0.135)\end{array}$ & $\begin{array}{l}0.0235 \\
(0.114)\end{array}$ \\
\hline
\end{tabular}




\section{Associate Rank}

Dummy

Area of Practice

Dummies

Year Dummies

Observations

$$
\text { Yes }
$$

Yes

Yes

7,655
Yes

Yes

Yes

989
Yes

Yes

Yes

467
Yes

Yes

Yes

2,457
Yes

Yes

Yes

815
Yes

$$
\text { Yes }
$$

Yes

405
Yes

Yes

Yes

363
Yes

No

Yes

391

es
Y 1

Yes

Yes

Yes

376

Notes: $* * * \mathrm{p}<0.01, * * \mathrm{p}<0.05, * \mathrm{p}<0.1$, Robust standard errors clustered by individual are in parentheses. Estimation is by probit. Dependent variable is exit, which is

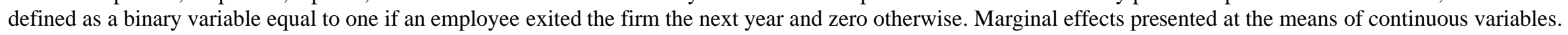
For binary independent variables, marginal effects reflect predicted probabilities when the variable increases from 0 to 1. 
Table 5: Reported Reasons for Leaving the Firm

\begin{tabular}{|c|c|c|c|c|c|c|}
\hline \multirow[b]{2}{*}{ Reason for Leaving } & \multicolumn{3}{|c|}{ Associates } & \multicolumn{3}{|c|}{ Managing Associates } \\
\hline & Male & Female & Difference & Male & Female & Difference \\
\hline Pulled Up & 0.18 & 0.15 & $0.034 *$ & 0.37 & 0.25 & $0.121 * * *$ \\
\hline Career Development & 0.17 & 0.14 & 0.03 & 0.26 & 0.22 & 0.04 \\
\hline Promotion/Partnership & 0.01 & 0.00 & $0.008 *$ & 0.11 & 0.03 & $0.085^{* * *}$ \\
\hline Pulled Sideways (Career) & 0.33 & 0.29 & $0.038^{*}$ & 0.28 & 0.29 & -0.01 \\
\hline Career Change & 0.17 & 0.15 & 0.02 & 0.12 & 0.15 & -0.03 \\
\hline Further Education/Study & 0.02 & 0.02 & 0.00 & 0.01 & 0.01 & 0.00 \\
\hline Management Style & 0.01 & 0.00 & $0.006^{*}$ & 0.01 & 0.00 & 0.01 \\
\hline To Travel & 0.00 & 0.01 & -0.01 & 0.01 & 0.01 & 0.00 \\
\hline To Work Internationally & 0.01 & 0.01 & 0.00 & 0.02 & 0.01 & 0.00 \\
\hline Type of Work & 0.05 & 0.04 & 0.01 & 0.03 & 0.04 & -0.01 \\
\hline Relocation & 0.07 & 0.06 & 0.01 & 0.08 & 0.06 & 0.02 \\
\hline Remuneration & 0.01 & 0.01 & 0.00 & 0.00 & 0.00 & 0.00 \\
\hline $\begin{array}{l}\text { Pulled Sideways } \\
\text { (Family/Lifestyle) }\end{array}$ & 0.07 & 0.15 & $-0.082 * * *$ & 0.06 & 0.19 & $-0.135 * * *$ \\
\hline Family/Personal Reasons & 0.02 & 0.06 & $-0.041 * * *$ & 0.02 & 0.11 & $-0.094 * * *$ \\
\hline Work-Life Balance & 0.03 & 0.07 & $-0.033 * * *$ & 0.03 & 0.08 & $-0.045^{* *}$ \\
\hline $\begin{array}{l}\text { Work } \\
\text { Environment/Culture }\end{array}$ & 0.01 & 0.01 & $-0.009^{*}$ & 0.01 & 0.00 & 0.01 \\
\hline \multicolumn{7}{|l|}{ Pulled Down } \\
\hline Disillusioned & 0.01 & 0.01 & 0.00 & 0.01 & 0.01 & 0.00 \\
\hline Pushed Out & 0.22 & 0.18 & $0.040 *$ & 0.13 & 0.14 & -0.01 \\
\hline Dismissal & 0.03 & 0.02 & 0.01 & 0.01 & 0.00 & 0.01 \\
\hline End of Contract & 0.01 & 0.01 & 0.00 & 0.00 & 0.02 & $-0.016^{*}$ \\
\hline Redundancy & 0.08 & 0.06 & 0.01 & 0.06 & 0.05 & 0.01 \\
\hline Firm Restructuring & 0.01 & 0.01 & 0.00 & 0.01 & 0.03 & $-0.022 *$ \\
\hline Counsel to Leave & 0.09 & 0.07 & $0.023^{*}$ & 0.05 & 0.04 & 0.02 \\
\hline Other & 0.18 & 0.20 & -0.02 & 0.12 & 0.10 & 0.03 \\
\hline Retirement & 0.00 & 0.00 & 0.00 & 0.00 & 0.00 & 0.00 \\
\hline Reason Not Known & 0.06 & 0.06 & -0.01 & 0.06 & 0.05 & 0.02 \\
\hline Other & 0.12 & 0.14 & -0.01 & 0.06 & 0.05 & 0.01 \\
\hline Total & 50.71 & 49.29 & 1.42 & 59.81 & 40.19 & $19.62 * * *$ \\
\hline $\mathrm{N}=$ & 1185 & 1152 & & 506 & 340 & \\
\hline
\end{tabular}

Notes: Numbers are the share of lawyers leaving the firm reporting each reason for their departure. Stars indicate the result of t-tests, $* * * \mathrm{p}<0.01, * * \mathrm{p}<0.05, * \mathrm{p}<0.1$. 
Table 6: Performance Ratings regressions

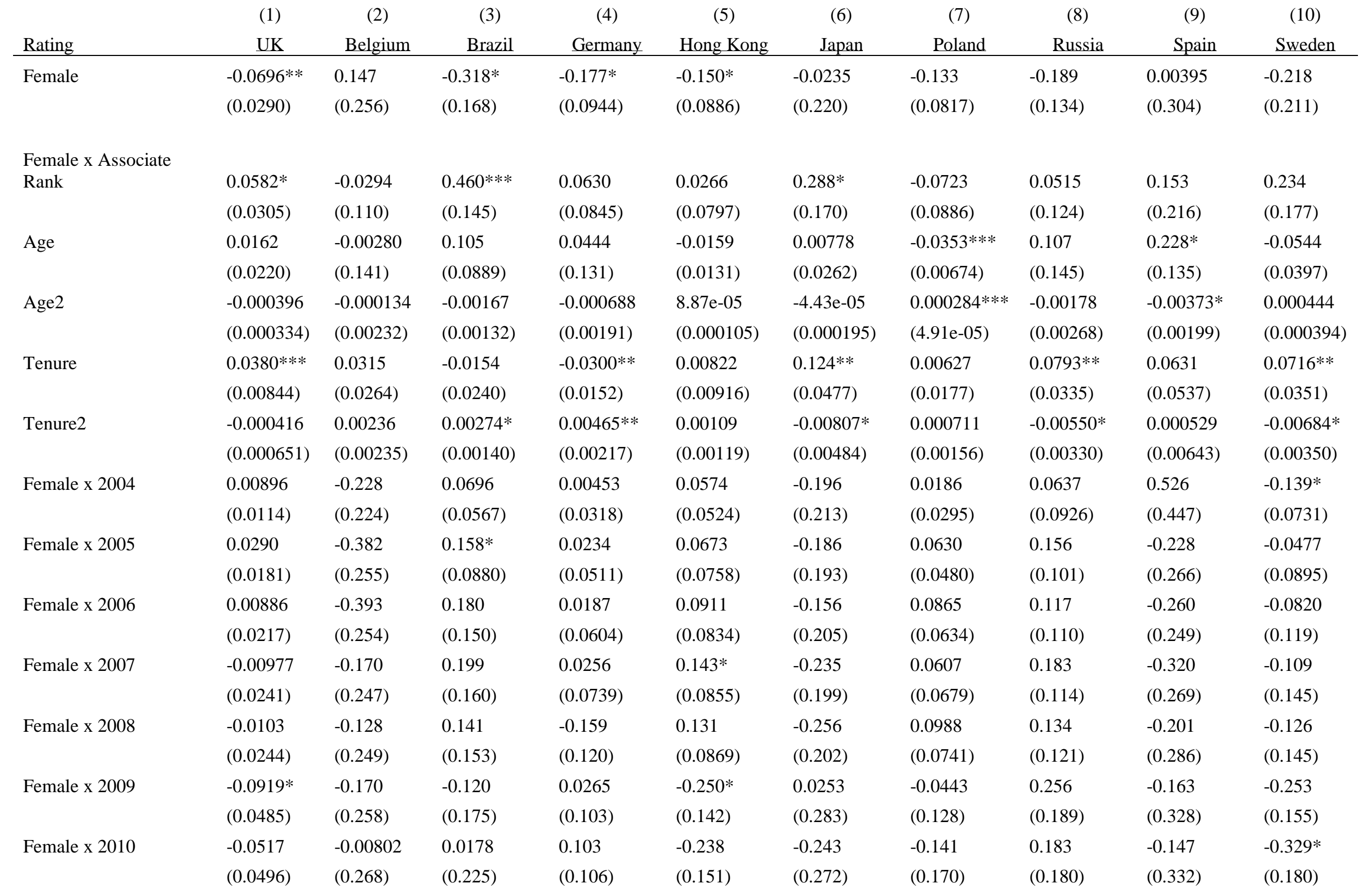




\begin{tabular}{|c|c|c|c|c|c|c|c|c|c|c|}
\hline $\begin{array}{l}\text { Associate Rank } \\
\text { Dummy } \\
\text { Area of Practice }\end{array}$ & Yes & Yes & Yes & Yes & Yes & Yes & Yes & Yes & Yes & Yes \\
\hline Dummies & Yes & Yes & Yes & Yes & Yes & Yes & Yes & Yes & Yes & Yes \\
\hline Year Dummies & Yes & Yes & Yes & Yes & Yes & Yes & Yes & Yes & Yes & Yes \\
\hline Observations & 7,303 & 751 & 400 & 1,018 & 739 & 340 & 334 & 379 & 291 & 688 \\
\hline R-squared & 0.287 & 0.296 & 0.205 & 0.150 & 0.353 & 0.498 & 0.383 & 0.541 & 0.376 & 0.184 \\
\hline
\end{tabular}

Notes: Robust standard errors clustered by individual are in parentheses. Estimation is by OLS. The dependent variable is the employee's performance rating, which is based on a 4-point scale for which each level corresponds to a clear definition of performance (performance level 4 being the top rank vs. performance level 1 being the bottom one). $* * * \mathrm{p}<0.01, * * \mathrm{p}<0.05, * \mathrm{p}<0.1$, Robust standard errors clustered by individual are in parentheses. Estimation is by OLS. 
Table 7: Log Wage regressions
(1)
(2)
(3)
(4)
(5)
(6)
(7)
(8)
(9)
(10)

\begin{tabular}{|c|c|c|c|c|c|c|c|c|c|c|}
\hline Ln Wages & $\underline{\mathrm{UK}}$ & Belgium & Brazil & Germany & Hong Kong & Japan & Poland & Russia & Spain & Sweden \\
\hline Female & $\begin{array}{l}-0.0438 * * * \\
(0.0145)\end{array}$ & $\begin{array}{l}-0.336 \\
(0.230)\end{array}$ & $\begin{array}{l}-0.00898 \\
(0.265)\end{array}$ & $\begin{array}{l}-0.0753 * * * \\
(0.0280)\end{array}$ & $\begin{array}{l}-0.0272 \\
(0.0337)\end{array}$ & $\begin{array}{l}0.0327 \\
(0.137)\end{array}$ & $\begin{array}{l}0.0189 \\
(0.173)\end{array}$ & $\begin{array}{l}0.0869 \\
(0.257)\end{array}$ & $\begin{array}{l}-0.243 * * \\
(0.0986)\end{array}$ & $\begin{array}{l}-0.155^{*} \\
(0.0842)\end{array}$ \\
\hline $\begin{array}{l}\text { Female x Assoc } \\
\text { Rank }\end{array}$ & $\begin{array}{l}0.0258 * * \\
(0.0129)\end{array}$ & $\begin{array}{l}0.286 \\
(0.197)\end{array}$ & $\begin{array}{l}0.287 \\
(0.252)\end{array}$ & $\begin{array}{l}0.0134 \\
(0.0283)\end{array}$ & $\begin{array}{l}0.0122 \\
(0.0410)\end{array}$ & $\begin{array}{l}0.217 \\
(0.145)\end{array}$ & $\begin{array}{l}-0.125 \\
(0.192)\end{array}$ & $\begin{array}{l}-0.349 \\
(0.282)\end{array}$ & $\begin{array}{l}0.151 * * \\
(0.0684)\end{array}$ & $\begin{array}{l}0.0869 \\
(0.0637)\end{array}$ \\
\hline Age & $\begin{array}{l}0.0857 * * * \\
(0.0104) \\
-\end{array}$ & $\begin{array}{l}0.149 * * * \\
(0.0556)\end{array}$ & $\begin{array}{l}0.231 * * * \\
(0.0675)\end{array}$ & $\begin{array}{l}0.0162 \\
(0.0297)\end{array}$ & $\begin{array}{l}0.0295 * * * \\
(0.00666) \\
-\end{array}$ & $\begin{array}{l}0.0578 * * * \\
(0.0148) \\
-\end{array}$ & $\begin{array}{l}0.0926 * * * \\
(0.0264) \\
-\end{array}$ & $\begin{array}{l}0.267 * \\
(0.140)\end{array}$ & $\begin{array}{l}0.0905^{* * * *} \\
(0.0109) \\
-\end{array}$ & $\begin{array}{l}0.0363 * * \\
(0.0177) \\
-\end{array}$ \\
\hline Age2 & $\begin{array}{l}0.000978 * * * \\
(0.000148)\end{array}$ & $\begin{array}{l}-0.00180^{*} \\
(0.000982)\end{array}$ & $\begin{array}{l}-0.00281 * * * \\
(0.000805)\end{array}$ & $\begin{array}{l}-0.000226 \\
(0.000440)\end{array}$ & $\begin{array}{l}0.000213 * * * \\
(4.95 \mathrm{e}-05)\end{array}$ & $\begin{array}{l}0.000403^{* * *} \\
(0.000110)\end{array}$ & $\begin{array}{l}0.000690^{* * *} \\
(0.000191)\end{array}$ & $\begin{array}{l}-0.00299 \\
(0.00242)\end{array}$ & $\begin{array}{l}0.000662 * * * \\
(8.21 \mathrm{e}-05)\end{array}$ & $\begin{array}{l}0.000420^{* *} \\
(0.000197)\end{array}$ \\
\hline Tenure & $\begin{array}{l}0.000126 \\
(0.00291)\end{array}$ & $\begin{array}{l}-0.0261 \\
(0.0282)\end{array}$ & $\begin{array}{l}-0.110 * * * \\
(0.0376)\end{array}$ & $\begin{array}{l}0.0134 * * \\
(0.00678)\end{array}$ & $\begin{array}{l}-0.00553 \\
(0.00376)\end{array}$ & $\begin{array}{l}0.105 * * * \\
(0.0340)\end{array}$ & $\begin{array}{l}-0.0651 * * \\
(0.0283)\end{array}$ & $\begin{array}{l}0.0928 * \\
(0.0514)\end{array}$ & $\begin{array}{l}-0.00141 \\
(0.0191)\end{array}$ & $\begin{array}{l}0.0752 * * * \\
(0.0133)\end{array}$ \\
\hline Tenure2 & $\begin{array}{l}0.000389 * \\
(0.000228)\end{array}$ & $\begin{array}{l}-0.00298 \\
(0.00208)\end{array}$ & $\begin{array}{l}0.00773 * * \\
(0.00314)\end{array}$ & $\begin{array}{l}-0.000558 \\
(0.00108)\end{array}$ & $\begin{array}{l}0.000187 \\
(0.000568)\end{array}$ & $\begin{array}{l}-0.00944 * * * \\
(0.00277)\end{array}$ & $\begin{array}{l}0.00401 \\
(0.00295)\end{array}$ & $\begin{array}{l}-0.0107 * * * \\
(0.00333)\end{array}$ & $\begin{array}{l}0.00253 \\
(0.00208)\end{array}$ & $\begin{array}{l}0.00265^{* * *} \\
(0.000602)\end{array}$ \\
\hline Female x 2004 & $\begin{array}{l}0.00249 \\
(0.0118)\end{array}$ & $\begin{array}{l}0.132 \\
(0.119)\end{array}$ & $\begin{array}{l}-0.126 \\
(0.0800)\end{array}$ & $\begin{array}{l}-0.0165 \\
(0.0174)\end{array}$ & $\begin{array}{l}0.0200 \\
(0.0321)\end{array}$ & $\begin{array}{l}-0.171 \\
(0.116)\end{array}$ & $\begin{array}{l}-0.0557 \\
(0.0699)\end{array}$ & $\begin{array}{l}-0.0869 \\
(0.0882)\end{array}$ & $\begin{array}{l}0.0252 \\
(0.106)\end{array}$ & $\begin{array}{l}0.0234 \\
(0.0260)\end{array}$ \\
\hline Female x 2005 & $\begin{array}{l}-0.00198 \\
(0.0117)\end{array}$ & $\begin{array}{l}0.149 \\
(0.145)\end{array}$ & $\begin{array}{l}-0.209 \\
(0.134)\end{array}$ & $\begin{array}{l}-0.0352 \\
(0.0258)\end{array}$ & $\begin{array}{l}-0.0330 \\
(0.0338)\end{array}$ & $\begin{array}{l}-0.338 \\
(0.227)\end{array}$ & $\begin{array}{l}-0.0759 \\
(0.0735)\end{array}$ & $\begin{array}{l}-0.115 \\
(0.0910)\end{array}$ & $\begin{array}{l}-0.0691 \\
(0.103)\end{array}$ & $\begin{array}{l}0.0501 \\
(0.0503)\end{array}$ \\
\hline Female x 2006 & $\begin{array}{l}0.00519 \\
(0.0127)\end{array}$ & $\begin{array}{l}0.190 \\
(0.160)\end{array}$ & $\begin{array}{l}-0.0578 \\
(0.268)\end{array}$ & $\begin{array}{l}-0.0156 \\
(0.0277)\end{array}$ & $\begin{array}{l}0.00338 \\
(0.0401)\end{array}$ & $\begin{array}{l}-0.128 \\
(0.104)\end{array}$ & $\begin{array}{l}-0.133 \\
(0.105)\end{array}$ & $\begin{array}{l}-0.0805 \\
(0.223)\end{array}$ & $\begin{array}{l}0.0258 \\
(0.120)\end{array}$ & $\begin{array}{l}0.0645 \\
(0.0555)\end{array}$ \\
\hline Female x 2007 & $\begin{array}{l}-0.00939 \\
(0.0146)\end{array}$ & $\begin{array}{l}0.191 \\
(0.169)\end{array}$ & $\begin{array}{l}-0.107 \\
(0.268)\end{array}$ & $\begin{array}{l}-0.0393 \\
(0.0318)\end{array}$ & $\begin{array}{l}0.0548 \\
(0.0383)\end{array}$ & $\begin{array}{l}-0.651 * * \\
(0.293)\end{array}$ & $\begin{array}{l}-0.180 \\
(0.167)\end{array}$ & $\begin{array}{l}-0.0981 \\
(0.210)\end{array}$ & $\begin{array}{l}-0.0419 \\
(0.117)\end{array}$ & $\begin{array}{l}0.0249 \\
(0.0584)\end{array}$ \\
\hline Female x 2008 & $\begin{array}{l}-0.00499 \\
(0.0130)\end{array}$ & $\begin{array}{l}0.214 \\
(0.190)\end{array}$ & $\begin{array}{l}-0.254 \\
(0.309)\end{array}$ & $\begin{array}{l}-0.00974 \\
(0.0301)\end{array}$ & $\begin{array}{l}0.0318 \\
(0.0371)\end{array}$ & $\begin{array}{l}-0.340 \\
(0.222)\end{array}$ & $\begin{array}{l}-0.187 \\
(0.206)\end{array}$ & $\begin{array}{l}-0.107 \\
(0.225)\end{array}$ & $\begin{array}{l}0.00938 \\
(0.100)\end{array}$ & $\begin{array}{l}0.0248 \\
(0.0583)\end{array}$ \\
\hline Female x 2009 & $\begin{array}{l}0.00417 \\
(0.0134)\end{array}$ & $\begin{array}{l}0.238 \\
(0.204)\end{array}$ & $\begin{array}{l}-0.147 \\
(0.368)\end{array}$ & $\begin{array}{l}0.0138 \\
(0.0318)\end{array}$ & $\begin{array}{l}0.00742 \\
(0.0353)\end{array}$ & $\begin{array}{l}-0.232 * \\
(0.120)\end{array}$ & $\begin{array}{l}-0.210 \\
(0.159)\end{array}$ & $\begin{array}{l}-0.269 \\
(0.277)\end{array}$ & $\begin{array}{l}0.0870 \\
(0.0981)\end{array}$ & $\begin{array}{l}0.0249 \\
(0.0578)\end{array}$ \\
\hline
\end{tabular}




\begin{tabular}{|c|c|c|c|c|c|c|c|c|c|c|}
\hline Female x 2010 & $\begin{array}{l}0.0112 \\
(0.0136)\end{array}$ & $\begin{array}{l}0.309 \\
(0.229)\end{array}$ & $\begin{array}{l}-0.352 \\
(0.328)\end{array}$ & $\begin{array}{l}0.00698 \\
(0.0340)\end{array}$ & $\begin{array}{l}-0.0367 \\
(0.0437)\end{array}$ & $\begin{array}{l}-0.236^{*} \\
(0.122)\end{array}$ & $\begin{array}{l}0.443 \\
(0.325)\end{array}$ & $\begin{array}{l}0.0621 \\
(0.169)\end{array}$ & $\begin{array}{l}0.0273 \\
(0.0973)\end{array}$ & $\begin{array}{l}0.0619 \\
(0.0641)\end{array}$ \\
\hline $\begin{array}{l}\text { Associate Rank } \\
\text { Dummy } \\
\text { Area of Practice }\end{array}$ & Yes & Yes & Yes & Yes & Yes & Yes & Yes & Yes & Yes & Yes \\
\hline Dummies & Yes & Yes & Yes & Yes & Yes & Yes & Yes & Yes & Yes & Yes \\
\hline Year Dummies & Yes & Yes & Yes & Yes & Yes & Yes & Yes & Yes & Yes & Yes \\
\hline Observations & 7,652 & 1,089 & 489 & 2,457 & 816 & 404 & 370 & 403 & 373 & 784 \\
\hline R-squared & 0.694 & 0.206 & 0.261 & 0.630 & 0.603 & 0.196 & 0.368 & 0.332 & 0.790 & 0.660 \\
\hline
\end{tabular}

Notes: $* * * \mathrm{p}<0.01, * * \mathrm{p}<0.05, * \mathrm{p}<0.1$, Robust standard errors clustered by individual are in parentheses. Estimation is by OLS. Dependent variable is log of wages. 
Table 8: Measures of National Culture

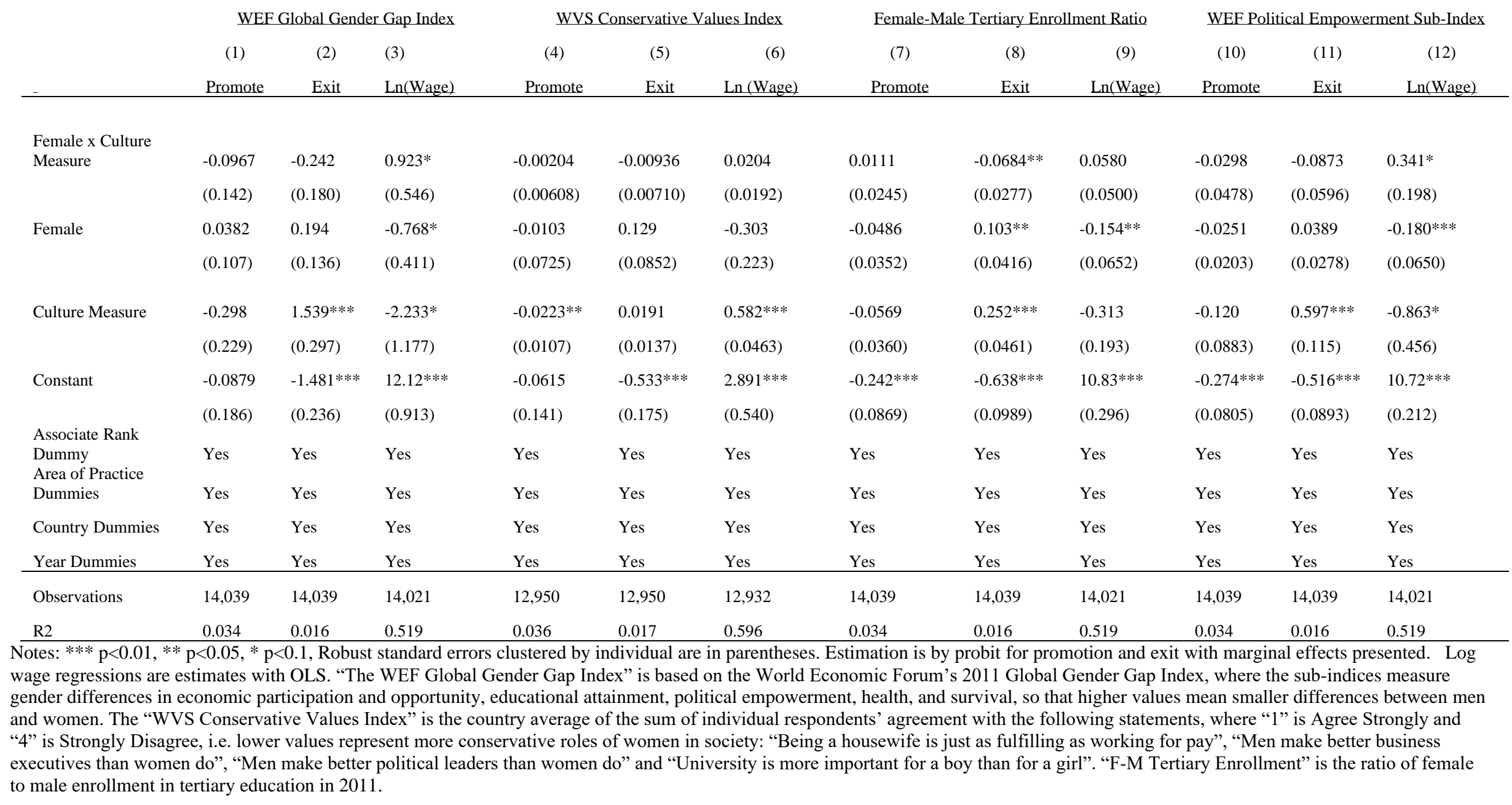

